\title{
Dilemas y vivencias frente a la implementación de la ley 1805 de 2016
}

\author{
Dilemmas and experiences caused by the implementation of the law 1805 of 2016
}

Dilemas e vivências perante a aplicação da lei 1805 de 2016

\author{
Gloria Omaira Bautista-Espinel ${ }^{l^{*}}$ \\ Carol Yuliett Ararat-Avendaño ${ }^{2}$ \\ Rossy Karina Hernández-Ortiz ${ }^{3}$ \\ Kelly Johana Villa-Cárdenas ${ }^{4}$
}

\begin{abstract}
Autor de correspondencia
${ }^{1 *}$ Enfermera profesional UFPS. Especialista en gerencia de los servicios de salud. Especialista en gestión aplicada a los servicios de salud. Especialista en práctica pedagógica universitaria. Magister en dirección de proyectos. Doctora en Bioética. Docente programa de enfermería Universidad Francisco de Paula Santander. Cúcuta, Colombia. Correo: gloriabautista@ufps.edu.co. iD

${ }^{2}$ Enfermera profesional UFPS. Enfermera Servicios Ambulatorios. Enfermera profesional del servicio de Promoción y prevención. Ese Imsalud. Cúcuta, Colombia. Correo: carolyuliettaa@ ufps.edu.co. (iD

${ }^{3}$ Enfermera profesional UFPS. Enfermera clínica. Enfermera profesional del servicio de ginecología/pediatría. Hospital Local de Puerto Asís. Puerto Asís (Putumayo), Colombia. Correo: rossykarinaho@ufps.edu.co. (ID)

${ }^{4}$ Enfermera profesional UFPS. Enfermera clínica. Enfermera profesional del servicio de UCI. Clínica Angiografia de Colombia. Villavicencio, Colombia. Correo: kellyjohanavillacardenas@ gmail.com. (D)
\end{abstract}

\section{Resumen}

En Colombia la ley 1805/2016, amplía la presunción legal de donación de órganos de todo adulto que en vida no exprese su negativa ante esta. Diversos posicionamientos involucran aspectos éticos y bioéticos, intensificando el debate moral y jurídico que la normativa suscita. El objetivo es analizar los dilemas bioéticos, que emergen en el personal de salud frente a la presunción legal de donación de órganos y las vivencias de pacientes en lista de espera, en el marco de la implementación de la ley 1805/2016. Materiales y métodos: Estudio fenomenológico, con triangulación múltiple y abordaje cualitativo, mediante entrevistas semiestructuradas, conversatorios y grupos focales. Informantes claves: 7 pacientes en lista de espera y 19 profesionales de salud de tres unidades de cuidados intensivos. Resultados: Se encontró que la implementación normativa convoca un tercer actor, la red de trasplante, que poco interactúa con el equipo de salud durante el rescate de órganos, situación que genera dilemas entre el principio de justicia distributiva, que involucra a los pacientes en lista de espera y el principio de respeto ante el duelo de los familiares del fallecido. Las tensiones de los pacientes se relacionan con el trasplante, que representa una esperanza de vida, rodeada de múltiples requerimientos. En conclusión, el personal de salud afronta dilemas bioéticos, por falta de educación y sensibilización normativa. Los pacientes experimentan tensiones éticas, que se sustentan en las vivencias de conductas previas, frente al anhelo del trasplante, visualizado como una segunda oportunidad.

Palabras clave: Receptores de trasplantes; trasplante de órganos; muerte encefálica; unidad de cuidados intensivos; bioética; personal de salud.

\section{Abstract}

In Colombia, the law 1805/2016, extends the legal presumption of organ donation to all adults who during life do not express denial regarding this matter. Diverse positionings involve ethic and bioethics aspects, intensifying the moral and legal debate caused by this law. Objective: Analyze the bioethical dilemmas that emerge in the

Recibido: 25 noviembre 2019 Aprobado: 6 abril 2020

Para citar este artículo/ To reference this article/ Para citar este artigo/

Bautista-Espinel Gloria Omaira; Ararat-Avendaño Carol Yulieth; Hernández-Ortiz Rossy Karina; Villa-Cárdenas Kelly Johana. Dilemas y vivencias frente a la implementación de la ley 1805 de 2016. Rev. cienc. cuidad. 2020; 17(2): 8-21. https://doi. org/10.22463/17949831.1655 
healthcare personnel regarding the presumption of legal donation and the experiences of patients in the waiting list, considering the law 1805/2016. Material and Methods: Phenomenological study with multiple triangulation and qualitative approach, through semi-structured interviews, round table discussions and focus groups. Key informants: 7 patients on the waiting list and 19 healthcare professionals from three intensive care units. Results: It was found that the implementation of this regulation convenes a third party, the organ and transplant network, which hardly interacts with the health team during the rescue of organs, a situation that generates dilemmas between the principle of distributive justice, involving the patients on the waiting list, and the principle of respecting the grief of the family of the deceased. The tensions of the patients are related to the transplant, which represents a hope for life, surrounded by multiple requirements. Conclusion: The health care personnel face bioethical dilemmas caused by the lack of education and sensibilization from the regulations. The patients experience ethical tensions, which are based on the experiences of previous behaviors regarding the longing for transplantation, visualized as a second opportunity.

Keywords: Transplant recipient; organ transplantation; brain death; intensive care unit; bioethics; healthcare personnel.

\section{Resumo}

Na Colômbia a lei 1805/2016, amplia a presunção legal de doação de órgãos a toda pessoa adulta que em vida não expresse a sua negativa perante a mesma. Diversos posicionamentos envolvem aspectos éticos e bioéticas intensificando o debate moral e jurídico que a norma suscita. Objetivo: analisar os dilemas bioéticas que se originam no pessoal de saúde perante a presunção legal de doação e as vivências de pacientes em espera de um órgão na implementação da lei 1805/2016. Materiais e métodos: Estudo fenomenológico, com múltipla triangulação e formulação qualitativa, realizando entrevistas semiestruturadas e grupos focais. Estudaram-se sete pacientes à espera de um órgão e 19 profissionais do setor saúde de três unidades de terapia intensiva. Resultados: Encontrouse que a norma envolve um terceiro participante, a rede de resgate dos órgãos, que tem mínima interação com a equipe de saúde durante o resgate dos órgãos, situação que gera conflito entre o principio de justiça distributiva, que envolve os pacientes à espera e o principio do respeito ante a perda dos familiares do doador. As tensões dos pacientes relacionam-se com o próprio transplante, que representa a esperança da vida, acompanhada de múltiplos requerimentos. Conclusão: O pessoal de saúde afronta diversos dilemas bioéticas, por falta de ensino e sensibilização normativa. Os pacientes experimentam tensões éticas, que se sustentam nas vivências de condutas previas frente a expectativa do transplante, percebido como uma segunda oportunidade.

Palavras-chave: Receptor do transplante; transplante de órgãos; morte encefálica; cuidados críticos; bioética; pessoal de saúde.

\section{Introducción}

En Colombia el marco legal sobre presunción legal de donación no es una disposición de fácil implementación, porque la ley no ha sido aún bien difundida. Para las familias, el cuerpo del recién fallecido no es un cadáver, sino que todavía es su pariente. Los deudos enfrentarán esta disposición justo en el inicio del duelo, por lo que puede existir una reacción negativa contra los trabajadores de la salud, las instituciones y el Estado mismo (1).

A pesar de los avances tecnológicos, la falta de donantes se constituye en una problemática, para los pacientes en lista de espera. La demanda por órganos aumenta rápidamente y la oferta, aunque se incremente, no es significativa en la mayoría de los casos, porque existe un trasfondo de desinformación y trámites administrativos que retrasan la obtención de órganos y que, de obtenerse de forma oportuna, salvarían muchas vidas (2).

En un escenario tradicional: "el profesional enfermero realiza inicialmente la entrevista familiar en relación al diagnóstico de muerte encefálica. Igualmente, debe informar ética, moral y legalmente acerca del proceso de captación y distribución de los órganos y tejidos a ser donados, y educar de manera clara y objetiva, respetando las opiniones de los familiares y su momento de pérdida y dolor" (3).

Con respecto al proceso previo al rescate de órganos, emergen dilemas bioéticos importantes, que no son ajenos a la enfermería. ¿Cuándo un individuo debería dejar 
de ser considerado paciente para comenzar a ser considerado donante? (4), o en qué momento se les explica a los familiares que el principio del permiso, planteado por Engelhardt (5) deja de ser un privilegio de las familias y se convierte en un imperativo legal. Desafio para el cual, la enfermería debe estar preparada.

\section{La reflexión desde la bioética: en torno a la donación y los trasplantes}

En Colombia, la ley 1805 de 2016 (6), que reemplaza las anteriores normas, que exigían al paciente en vida identificarse como donante, genera inquietudes que ameritan ser reconocidas e interpretadas. La Red de Donación y Trasplantes de Órganos y Tejidos, es el conjunto de entidades relacionadas con los procesos de donación y trasplante en el país. El grupo de donación y trasplantes ejerce la coordinación nacional de Donación y Trasplantes, incluidos los procesos de obtención, preservación, almacenamiento, trasporte, destino y disposición final de los órganos y tejidos (7). Hay que precisar, que actualmente Norte de Santander, no cuenta con entidades adscritas a la red. En este caso, la red asume la preparación psicológica del familiar del donante y el grupo de rescate la preparación del donante. El equipo de salud es relevado de sus funciones directas con familiares y donante potencial.

Según datos del Ministerio de Protección Social, actualmente unos 2.600 colombianos están en lista de espera para trasplante; dichas listas son encabezadas especialmente por trasplante de riñón (2.437) e hígado (127). El promedio anual de donantes entre $2015 \mathrm{y}$ 2016 fue de 420 (8).

Dentro de este marco, estudios demuestran que por cada donante se pueden beneficiar decenas de personas, es decir, que "Con un donante, incluso, se puede llegar a ayudar hasta a 55 pacientes". Sin embargo, a pesar de estos intentos, las necesidades de donantes son mayores, frente a los requerimientos de una población con gran carga de la enfermedad, que padece un sinnúmero de patologías de tipo crónico, agudizando el fenómeno. Esta situación, hace que continúen falleciendo, gran número de pacientes, que permanecen en una lista de espera (9).

En este sentido, hay que señalar, que en el proceso de la donación se involucran diferentes aspectos científicos, religiosos, culturales, bioéticos y legales. En consecuencia, hay que involucrar estos criterios cuando existe muerte cerebral; igualmente, deberían tenerse en cuenta a la hora de dictaminar la condición de donante potencial del fallecido (10).

\section{La donación y el contexto interdisciplinario en salud}

Inicialmente el cuidado de la Enfermería respecto al paciente trasplantado, se centraba en prevenir las infecciones que desencadenaban el rechazo del órgano y el apoyo emocional. En esta situación se consideraba a las enfermeras como parte activa del equipo interdisciplinario. Actualmente, el profesional de la Enfermería juega un importante papel en el contexto del trasplante de órganos. De ahí, que dentro del equipo multidisciplinario que conforma las Unidades de Trasplantes, la Enfermería debe poseer los conocimientos, la experiencia clínica y la habilidad en la gestión de los servicios, de tal forma que le permitan liderar y organizar todas las actividades inherentes al trasplante (11).

\section{Bioética de la donación}

Por otra parte, entran en juego los principios bioéticos, que interactúan entre sí y generan contraposiciones, por ejemplo, el principio de autonomía, que se pone en entredicho para las familias e inclusive para el mismo paciente, si éste no logra expresar su voluntad anticipada sobre la negativa de donación. Además, la norma lo que busca es proteger el principio de justicia distributiva, que pretende llegar a más personas con escasa posibilidad de ser beneficiadas por donantes voluntarios de órganos (12).

La Autonomía: [...] se refiere al autogobierno, libre de interferencias controladoras y de limitaciones personales que impidan decisiones racionales (12). Estos aspectos se consideraban fundamentales para la donación, y que, a la luz de la nueva norma, pueden pasar a un segundo plano "si en vida la persona, no expresa lo contrario".

Beneficencia: Para algunos autores, desde una perspectiva ética consecuencialista y atendiendo el principio de utilidad, los procesos previos al trasplante, al estar encaminados a conseguir un beneficio para un mayor número de personas; es decir, que no podría realizarse sin el empleo de estos procedimientos [...] y por lo tanto hay tener en cuenta su mejor interés (beneficencia). Si se facilitan a su vez las maniobras de extracción de órganos y la agresividad quirúrgica del explante (no maleficencia), tendrán sentido si existe [...] una ética del trasplante pública, sincera, controlada. Además, debe estar expuesta a la revisión, basada en el beneficio no contrapuesto del donante y del receptor; esto es, que se considere al donante como provisto de la máxima dignidad, indispo- 
nibilidad e inviolabilidad; por tanto, hay que adoptar la norma personalista en beneficio del donante y receptor, en sustitución del principio de utilidad, aspecto que los autores esperan de los frutos que hasta ahora en algunos países, se ha conseguido (13).

No maleficencia: En las actividades de donación y trasplante se busca un bien común, en el cual no se cause daño a ninguno de los actores, solo para lograr la obtención de un órgano para un posible receptor que se encuentra en lista de espera. En este caso se habla de no maleficencia, ya que se antepone el hecho de cuidar y preservar la integridad de los presuntos donantes y su familia, ante la necesidad de un órgano para un paciente que lo requiere para mejorar su calidad de vida (14).

Justicia: En el sistema moral de referencia en el que la igualdad comparte hegemonía con la libertad, la justicia se vuelve el principio moderador que limita los excesos de libertad cuando perjudica a los demás; por tanto, la decisión de ser donante ya no es exclusivamente un acto de libertad que depende del presunto donante y del equipo encargado de la extracción del órgano (15).

\section{Las vivencias desde la sociología fenomenológica de Alfred Schutz}

En la teoría socio fenomenológica de Alfred Schütz, la vida cotidiana constituye nuestra realidad, el campo donde se llevan a cabo los proyectos y planes de vida; es un mundo dado a experiencias e interpretaciones propias, el cual es experimentado como un mundo intersubjetivo; es decir, compartido con otros semejantes con los cuales nos relacionamos a través de distintas relaciones sociales (16).

\section{Objetivos}

\section{Objetivo general}

Analizar los dilemas bioéticos, que emergen en el personal de salud, frente a la presunción legal de donación y las vivencias de pacientes en lista de espera, en el marco de implementación de la ley 1805 del 2016, en la ciudad de Cúcuta.

\section{Objetivos específicos}

- Establecer la representación social que el personal de salud de la Unidad de Cuidados IntensivosUCI, tiene sobre la presunción legal de donación en el desarrollo de su labor.
- Indagar acerca de las tensiones bioéticas que el personal de salud en la UCI, enfrenta al momento de notificar la presunción de donación a los familiares de donantes potenciales.

- Identificar los principios bioéticos que emergen ante las tensiones bioéticas en los miembros del equipo de salud, frente a las vivencias de los familiares de donantes potenciales.

- Conocer las vivencias de los pacientes en lista de espera, ante la presunción legal de donación.

\section{Materiales y métodos}

Se realizó un estudio cualitativo, de tipo fenomenológico en San José de Cúcuta (Colombia), durante el II semestre de 2017 y el I semestre de 2018, tomando como campo de interpretación las corrientes teóricas del Principialismo de Beauchamp y Childress (17).

Cabe destacar, que el marco epistemológico-metodológico para el análisis temático está fundamentado en la fenomenología social de Schutz (1932/1967). Desde este planteamiento, se considera que las personas que viven en el mundo de la vida cotidiana son capaces de atribuir significado a una situación; por tanto, hay que tener en cuenta, el significado subjetivo de la experiencia (18).

Adicionalmente se realizó una triangulación múltiple según lo descrito por Denzin, quien propone la utilización simultánea de por lo menos dos procedimientos. En este caso se tomó en cuenta la triangulación de datos y la triangulación de teorías, lo anterior con el abordaje cualitativo, teniendo en cuenta lo descrito por Betrián et al., (19).

Etapas del estudio: a) Personal de salud, se desarrollaron tres conversatorios y tres grupos focales en tres entidades de salud de alta complejidad; b) Los pacientes, mediante entrevistas semiestructuradas en dos ciclos de encuentros; $y, c)$ Triangulación múltiple de las fuentes de datos que resultaron de la investigación, a la luz de los aportes de los distintos participantes, el análisis de datos secundarios de fuentes oficiales y otros estudios publicados sobre el tema, para contrastar los resultados obtenidos. En la triangulación Teórica se utilizó la teoría principialista de Tom L. Beauchamp y James F. Childress; el contraste teórico, desde la fenomenología de Alfred Schütz y la teoría del significado. 
ISSN-PRINT

1794-9831

E-ISSN 2322-7028

Vol. 17 No. 2

May - Ago 2020

Cúcuta, Colombia
Informantes claves: personal de salud de tres Unidades de Cuidados Intensivos (UCI) y pacientes en lista de espera para trasplante de riñón del municipio de Cúcuta. La muestra fue ubicada en tres entidades de salud privadas, con la participación de 19 profesionales de salud y de 7 pacientes inmersos en el proceso de espera para trasplante. La selección del personal de salud participante fue por conveniencia, sobre la disponibilidad de tiempo y espacio brindado por las instituciones; los pacientes fueron elegidos de manera intencional por muestreo "bola de nieve", teniendo en cuenta los criterios de inclusión establecidos.

El sistema de procesamiento de la información abarcó los procesos de análisis, codificación, reducción de datos e interpretación de resultados, de acuerdo con lo descrito por Miles y Huberman (20). El análisis de datos se hizo con ayuda del software QDA (análisis cualitativo de datos) ATLASti.

Se garantizaron los aspectos éticos requeridos en estudios con seres humanos, de acuerdo con la resolu- ción 008430 de 1993 (21). Además, se contó con el aval institucional de los comités de ética de cada una de las instituciones de salud participantes.

\section{Resultados}

Los resultados se presentan de dos formas: primero las entrevistas a pacientes en lista de espera y en segundo lugar, los obtenidos mediante grupos focales con el personal de salud.

\section{Entrevistas Semiestructuradas a Informantes Pa- cientes en lista de espera}

Participó un total de 7 pacientes en lista de espera para donación, de los cuales 2 fueron de género masculino y 5 de género femenino. El rango de edad de los participantes fue de 34 a 64 años con un promedio de edad de 52 años, pertenecientes a estratos socioeconómicos 1 y 2; el tiempo promedio que llevan en lista de espera osciló de 3 meses a 7 años. El análisis de las entrevistas a los pacientes arrojó 13 categorías, que se agruparon en 6 familias. Ver Tabla 1.

Tabla 1. Clasificación de categorías en pacientes.

\begin{tabular}{ll}
\hline \multicolumn{1}{c}{ Categorías } & \multicolumn{1}{c}{ Familias } \\
\hline $\begin{array}{l}\text { Principios Bioéticos } \\
\text { Altruismo de la Donación }\end{array}$ & BIOÉTICA DE LA DONACIÓN \\
$\begin{array}{l}\text { Pluralidad Frente a la Donación } \\
\text { Los Valores de la Persona y los Derechos }\end{array}$ & DILEMAS \\
$\begin{array}{l}\text { Humanos } \\
\text { Patrón Cultural }\end{array}$ & \\
$\begin{array}{l}\text { Idea de "Integridad Personal" } \\
\text { Confrontación de Sentimientos }\end{array}$ & AUTOPERCEPCIÓN Y CAPACIDAD DEL \\
$\begin{array}{l}\text { Conocimiento Operativo } \\
\text { Compresión y Motivos }\end{array}$ & CONOR PARA INTERPRETAR EL MUNDO \\
$\begin{array}{l}\text { Discernimiento } \\
\text { Apoyo Social } \\
\text { Adoptando Nuevos Estilos de Vida } \\
\text { Expectativas a Futuro }\end{array}$ & IMPLICACIONES E IMPACTOS SOCIALES \\
\hline
\end{tabular}

Fuente: Autores.

\section{Bioética de la donación}

Los informantes expresan que la beneficencia es el acto generoso de ayudar a los demás sin esperar nada a cambio, donde solo se busca el bien común entre ellos, apoyados por la nueva ley de donación. Esta actitud se evidencia como sigue:
E1. I4:" Yo si quiero ser donante, de mis órganos, para salvar otra vida, sin egoísmo, sin odio, sin envidia, ni...ni interés" o E1. I3:" Pues algunos si dicen yo que me muriera, yo si a donaría mi riñón, a donaría todos los órganos que los ojos, bueno los órganos que yo tenga buenos...". 
En otros casos, se considera a la beneficencia como el acto que, a pesar de no ser para ellos, les alegra que pueda aportar a los demás:

E2. I6: "me gustaría que salven vidas asi porque, porque, así como yo estoy aferrada a la vida hay muchas personas también esperando".

La dimensión de la negación a la donación manifestada por los informantes se refleja desde el punto de vista de no querer hacer daño a su familiar (no maleficencia), si éste desea aportar a su recuperación por medio de la donación, como es el caso:

E1. I3: "el hijo dice que él me dona el riñón, él es el único hijo varón y él dice que, si el riñón de él es compatible con el mío, que él me acepta, que él me regala el riñón, aunque yo no quiero porque él se queda con un solo riñoncito".

Aunque en otros casos, los informantes manifiestan no querer dar sus órganos a otra persona (Justicia distributiva) como se evidencia en:

\section{E1. I3:" ;Yo donar, pues no! Todavía no, eso ir a do-} nar, ir yo a donar no...".

\section{Dilemas}

En esta categoría se encuentran realidades vividas y verbalizadas por los pacientes, respecto a su proceso de enfermedad e ingreso a la lista de espera, así como los consensos necesarios para aceptar dichas situaciones, como se evidencia a continuación:

E1. I3: "hay que tener paciencia ...porque hay mucho con los deseos de trasplantarse y estamos muchos en esa espera...".

Por otro lado, las concepciones, imaginarios sociales y sentimientos de duda e impotencia limitan a la sociedad en general a no donar, lo que se cataloga como una barrera. En este caso, se observan vacíos de información en la población.

E1. I1: "todavía falta mucho...mucho conocimiento de esto creo yo, inclusive creo yo que para las mismas personas que trabajan ahi, le hacen a uno eso".

En general, los pacientes consideran que existen diversas barreras en torno a la temática, que impiden que la población en general done de manera voluntaria; sin embargo, se encontraron algunas excepciones como lo son la cultura, los idealismos creados por la sociedad, la religión o el egoísmo, como lo manifiesta el siguiente participante:
E1. I6: "pues el tráfico de órganos es muy común en todos los países, no lo he visto, no lo, no lo sé, como harán eso, pero si lo hay claro". E1. I2: "pues sí, porque cada familia no creamos según la religión y

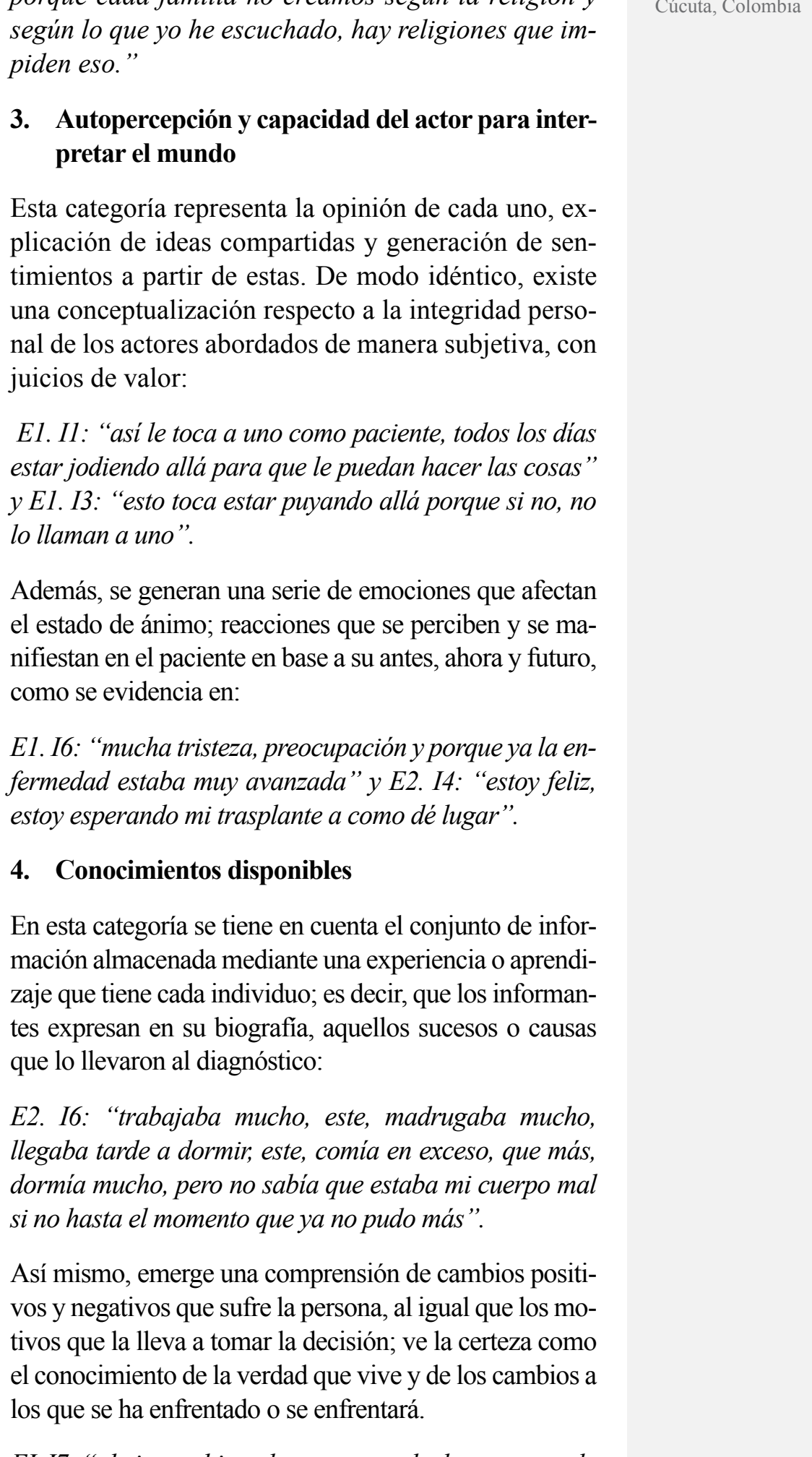

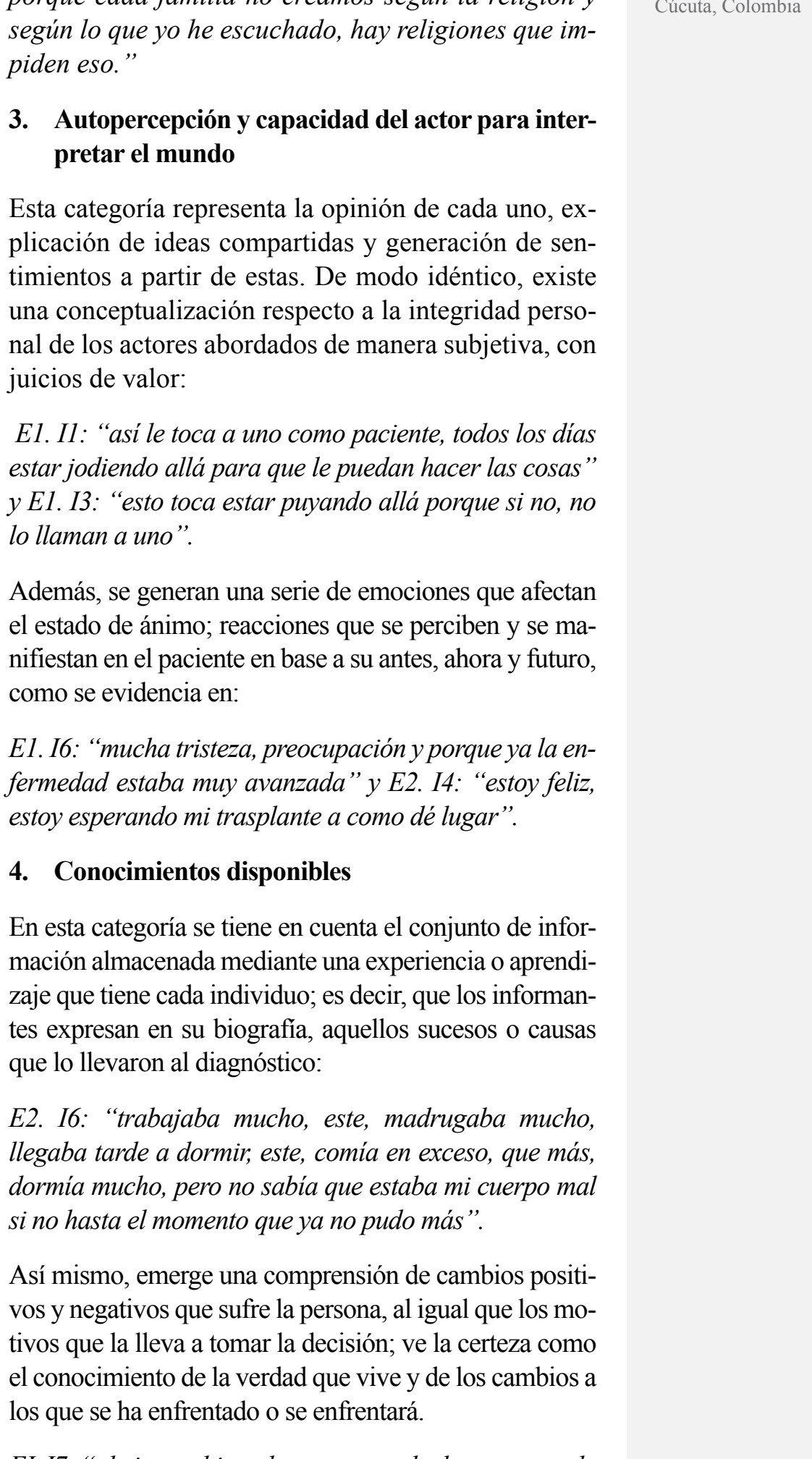

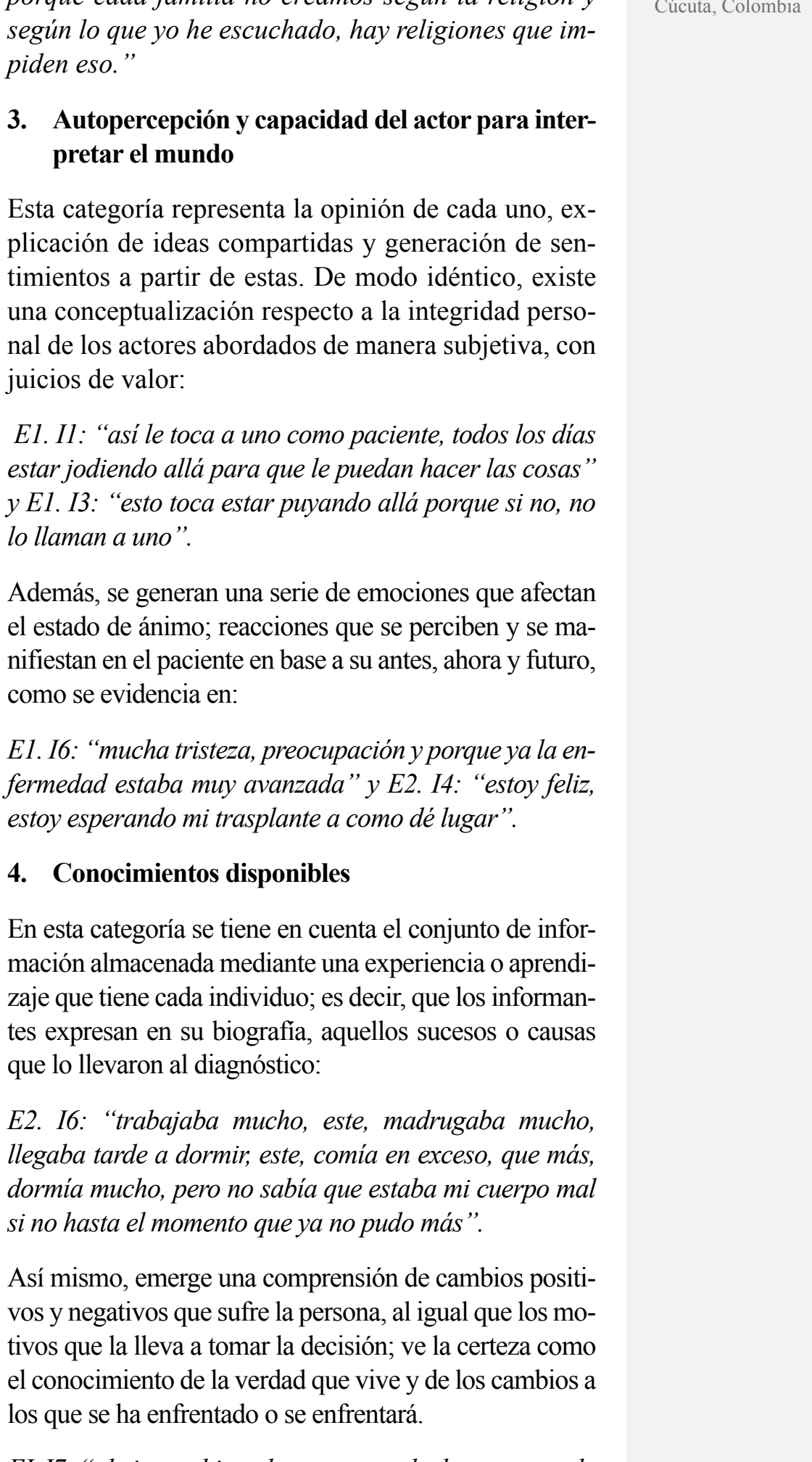

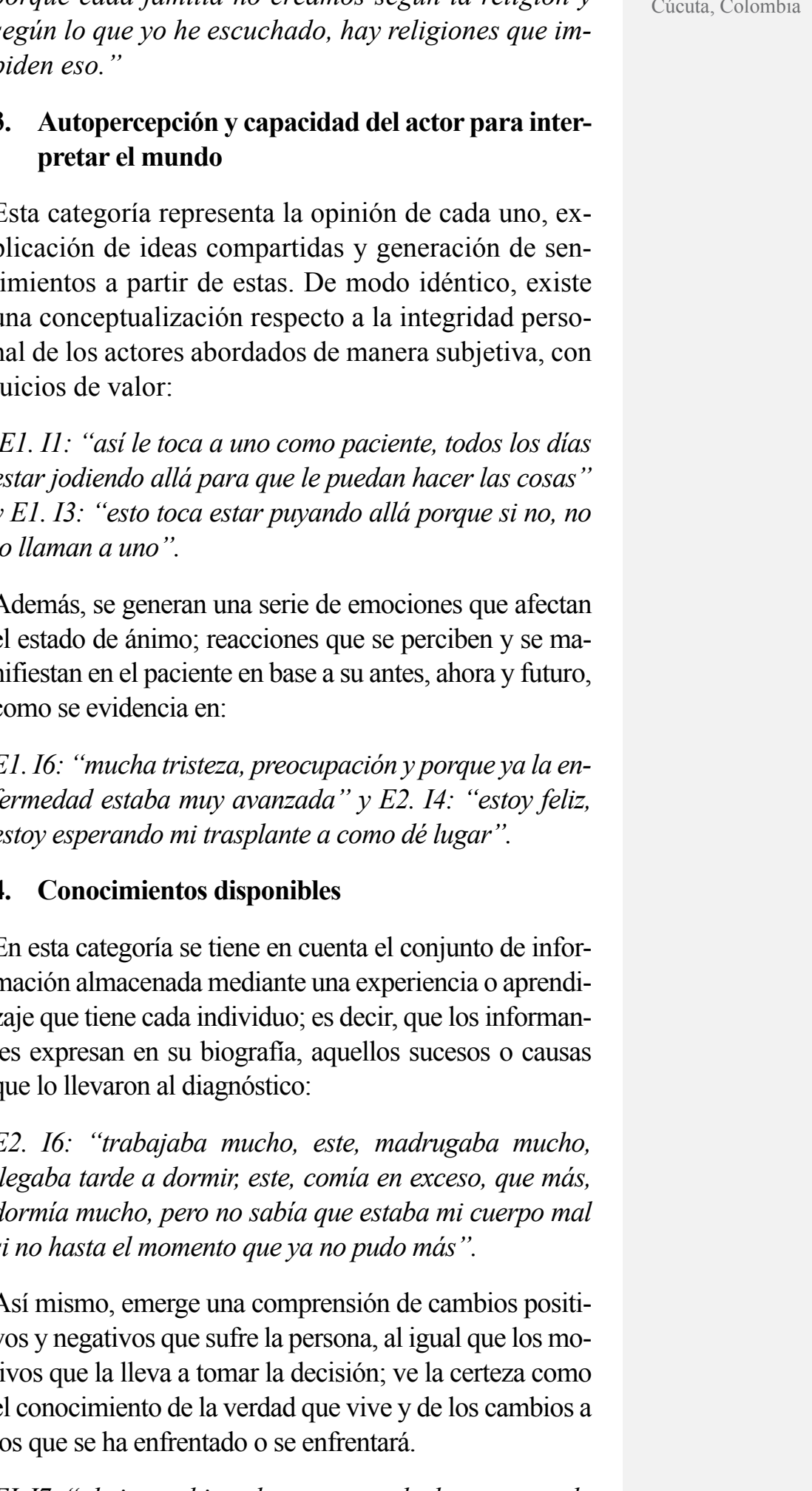

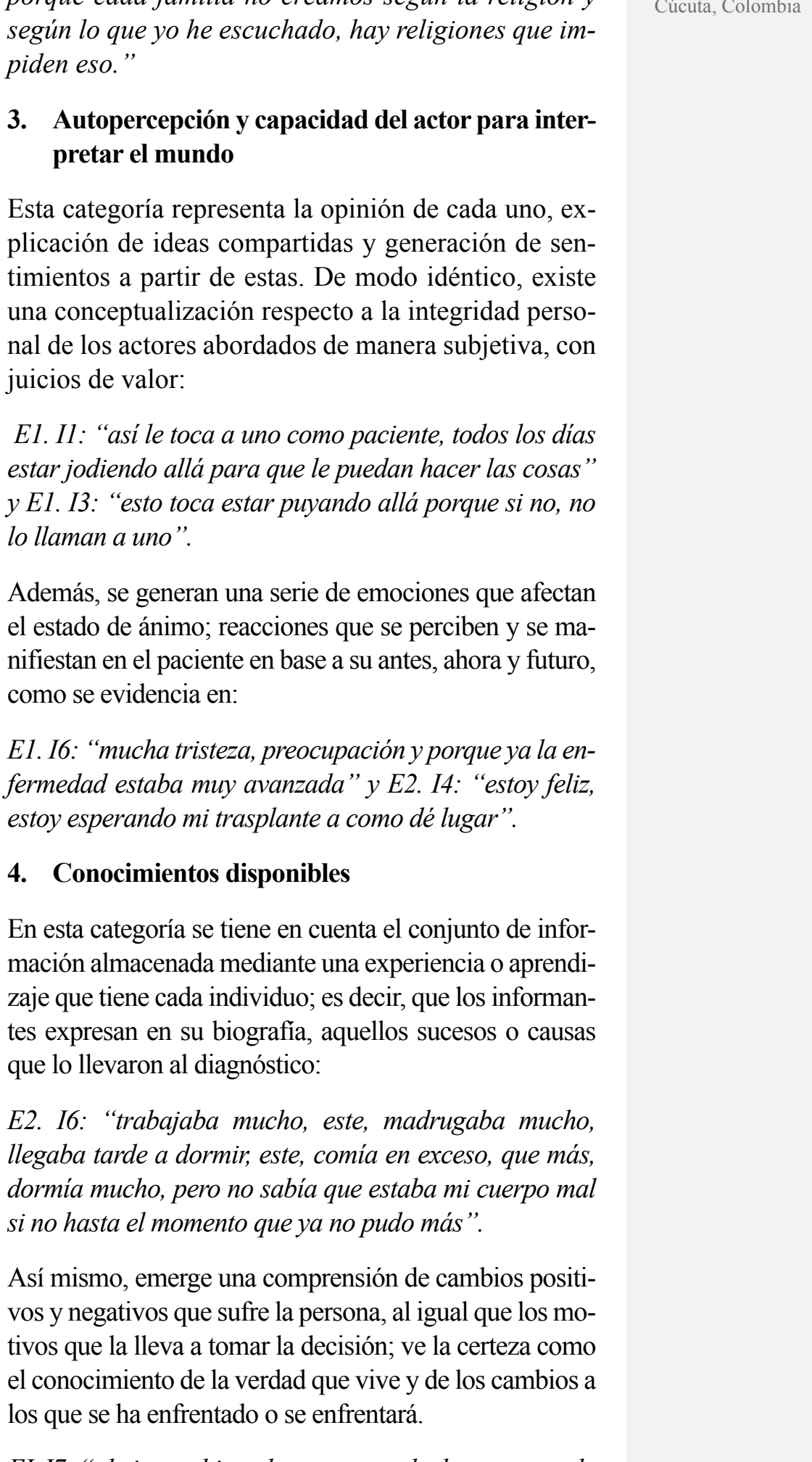

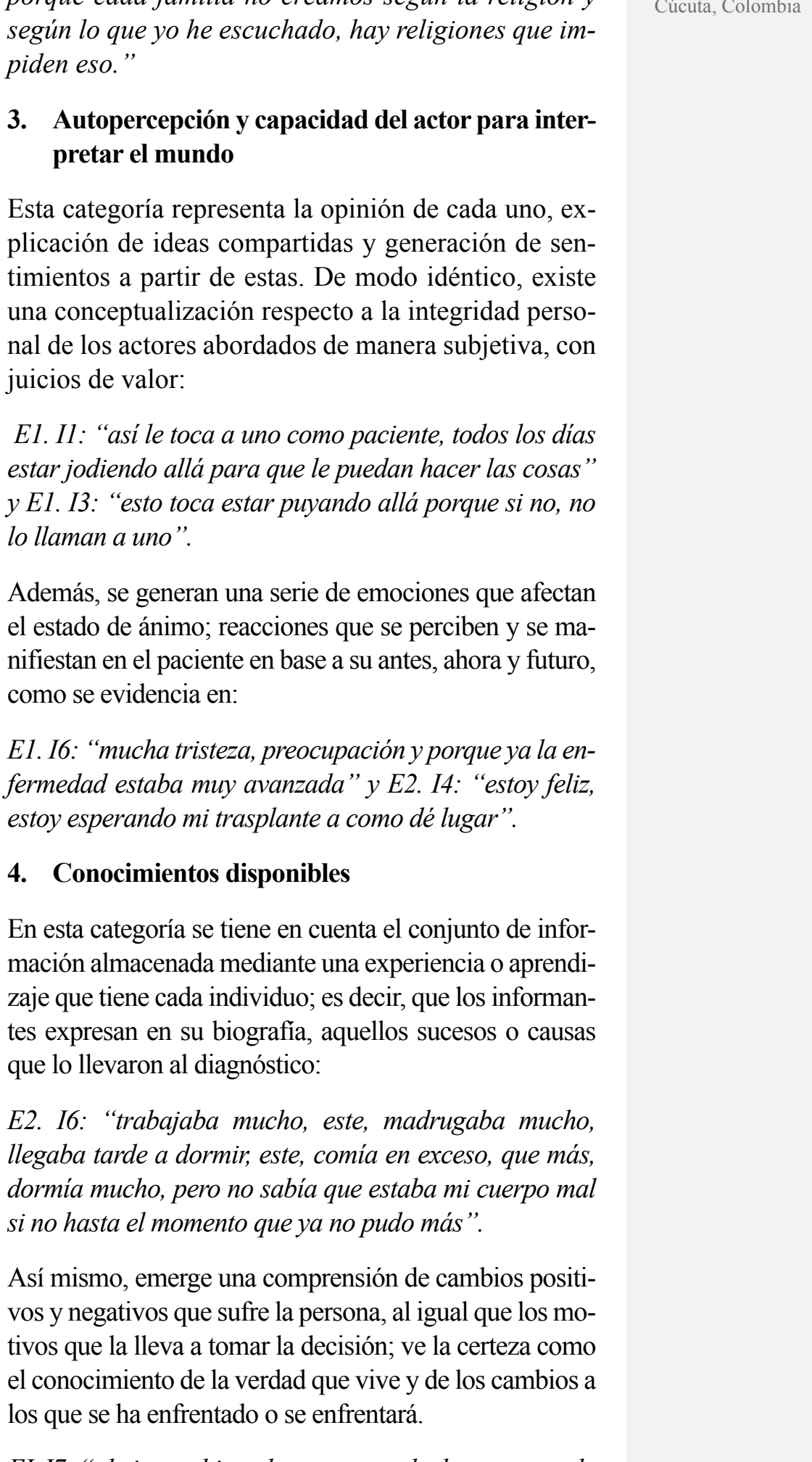

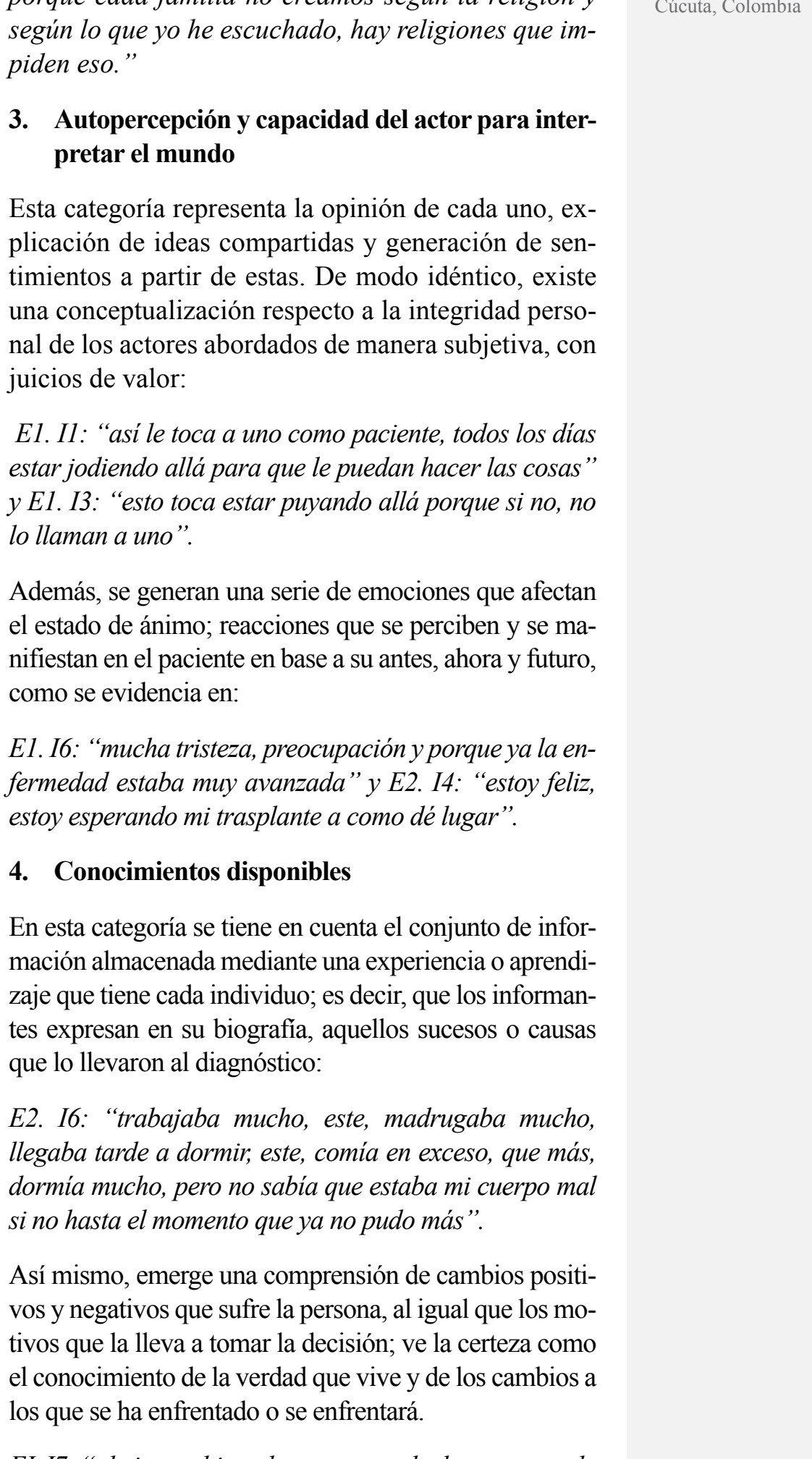

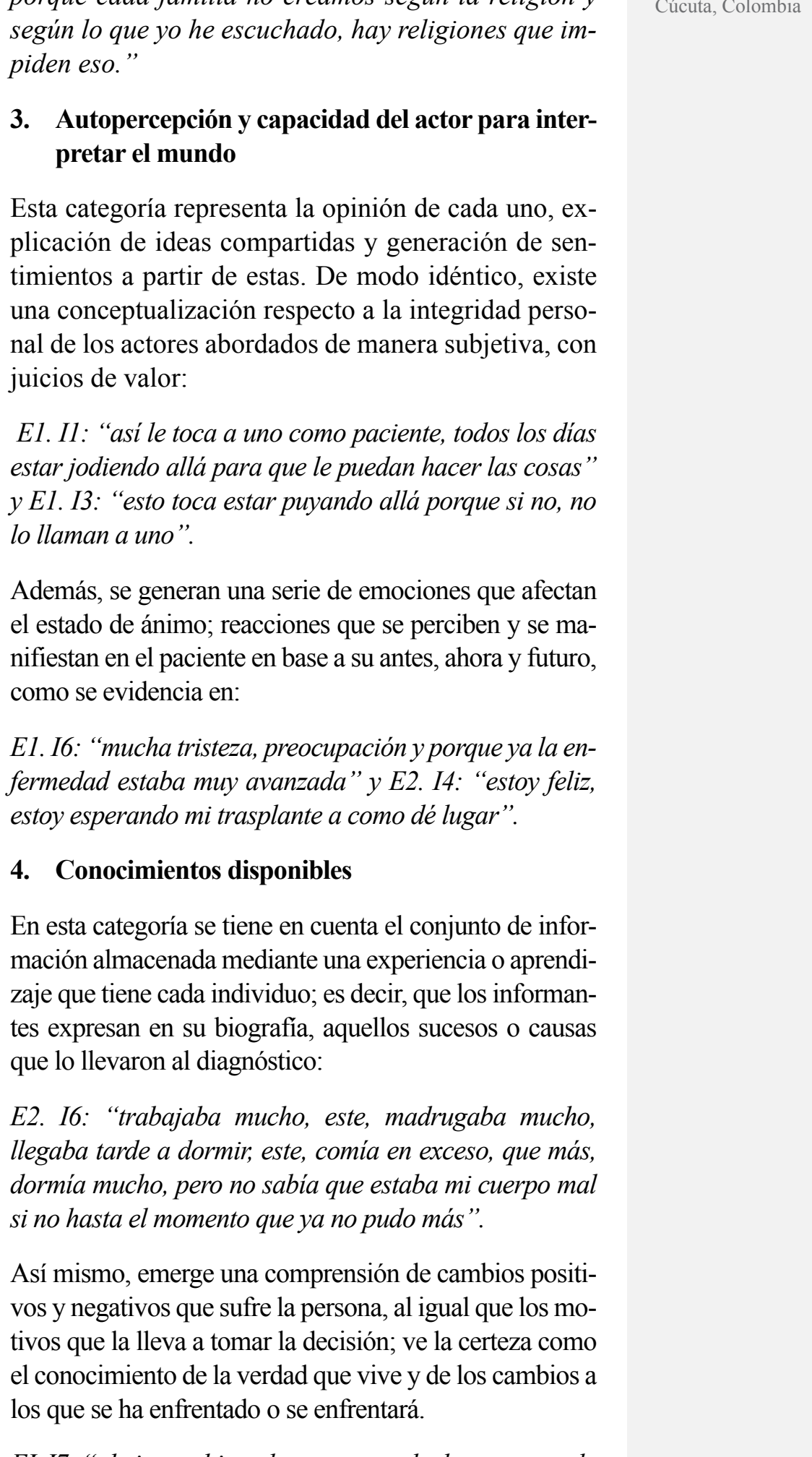

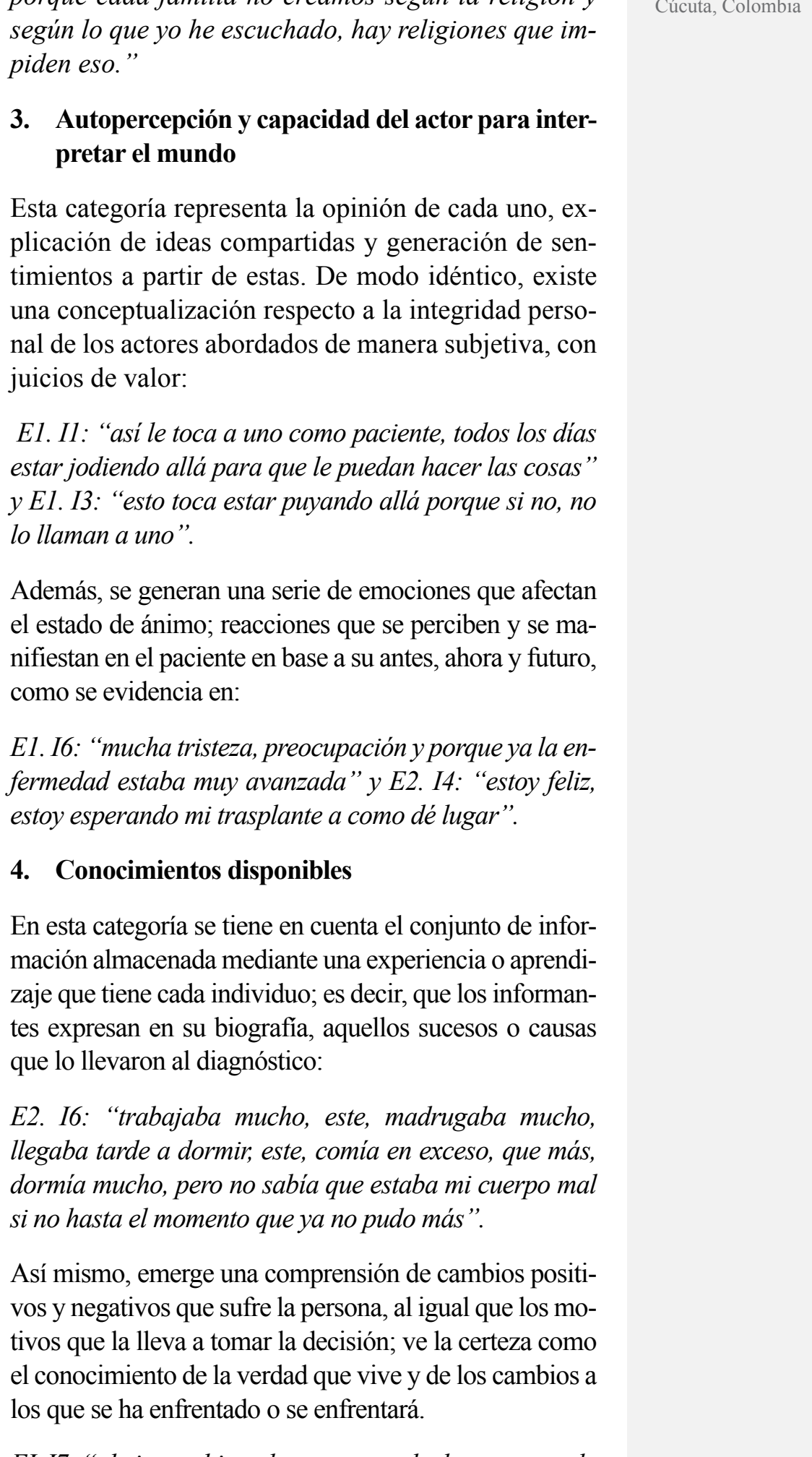

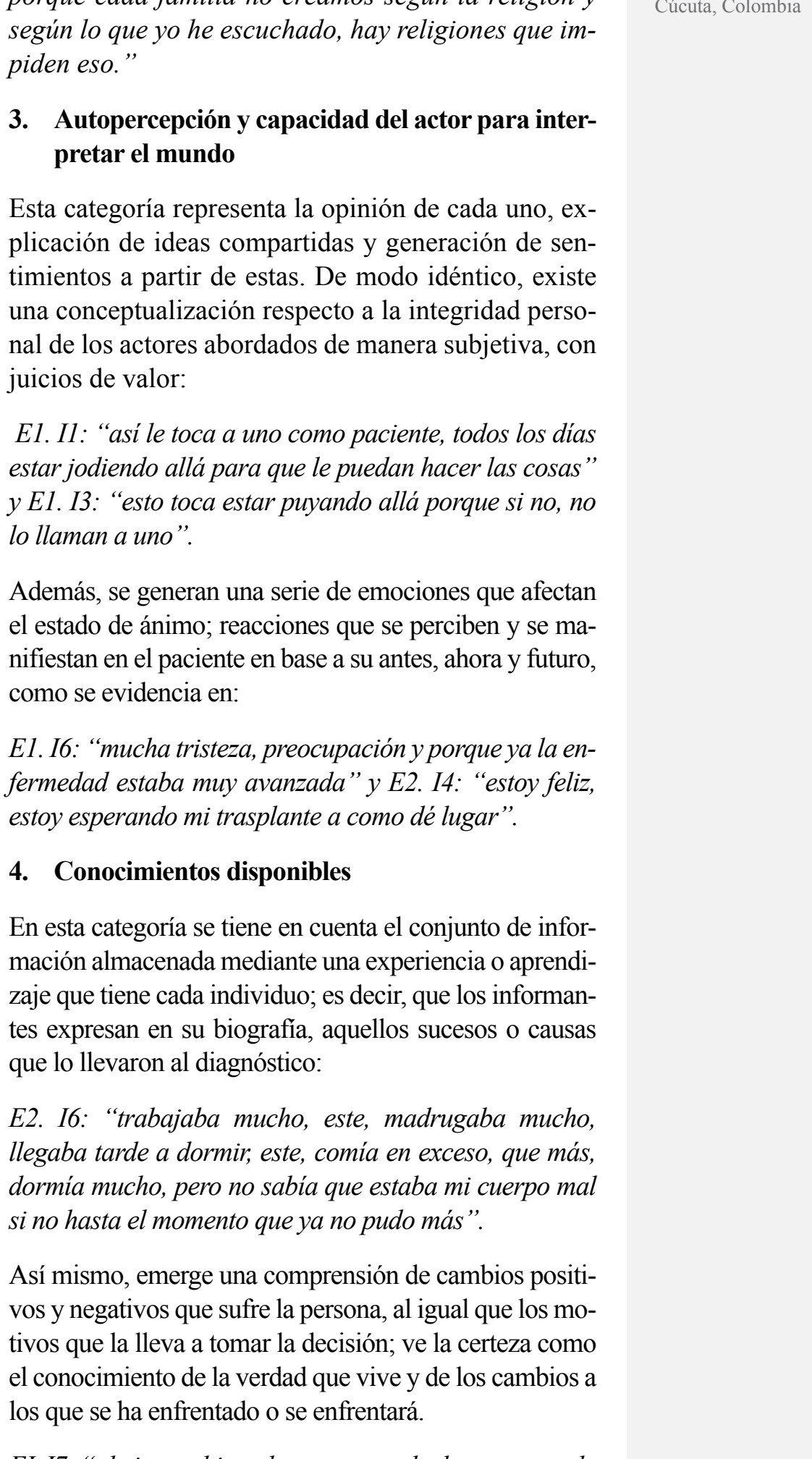

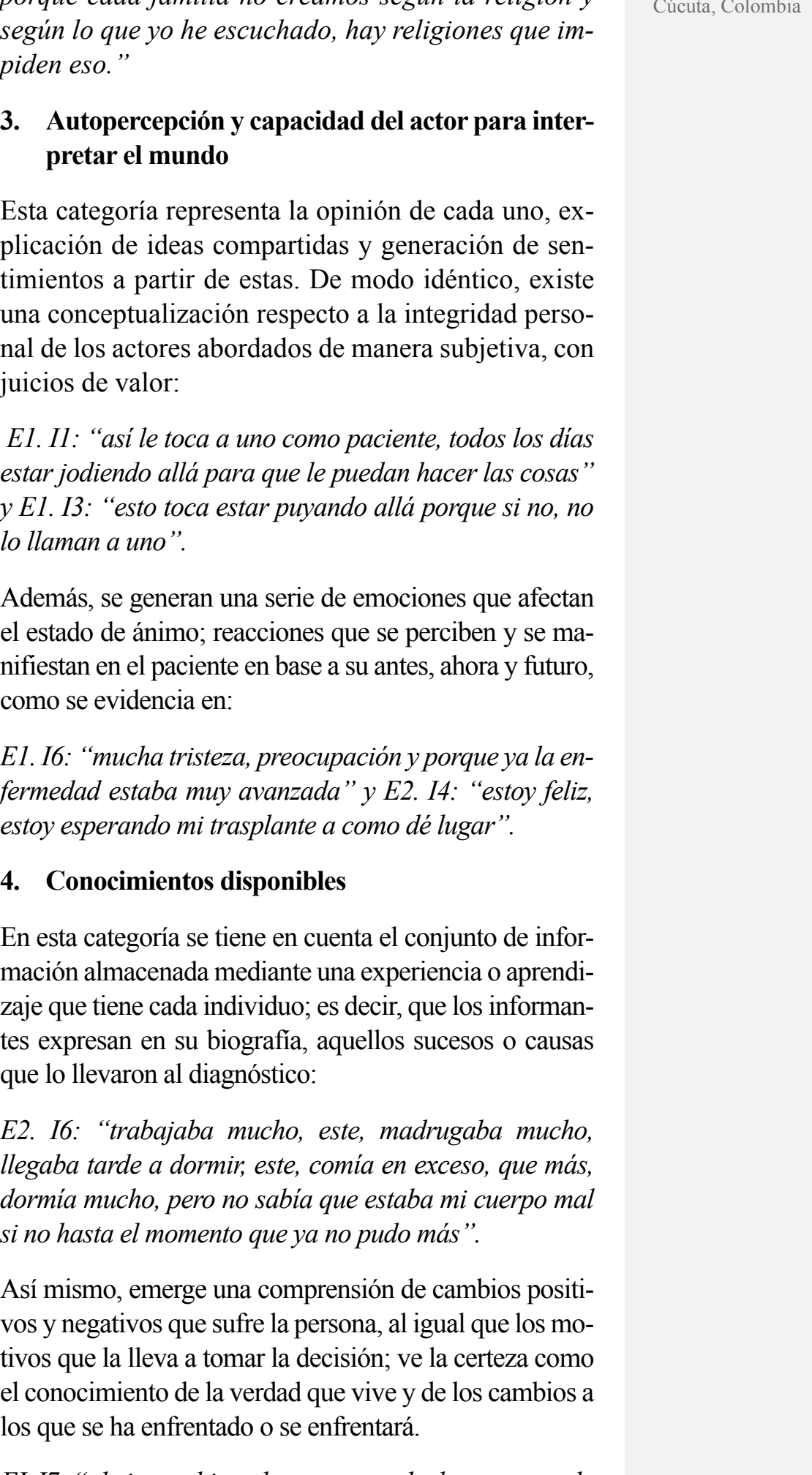

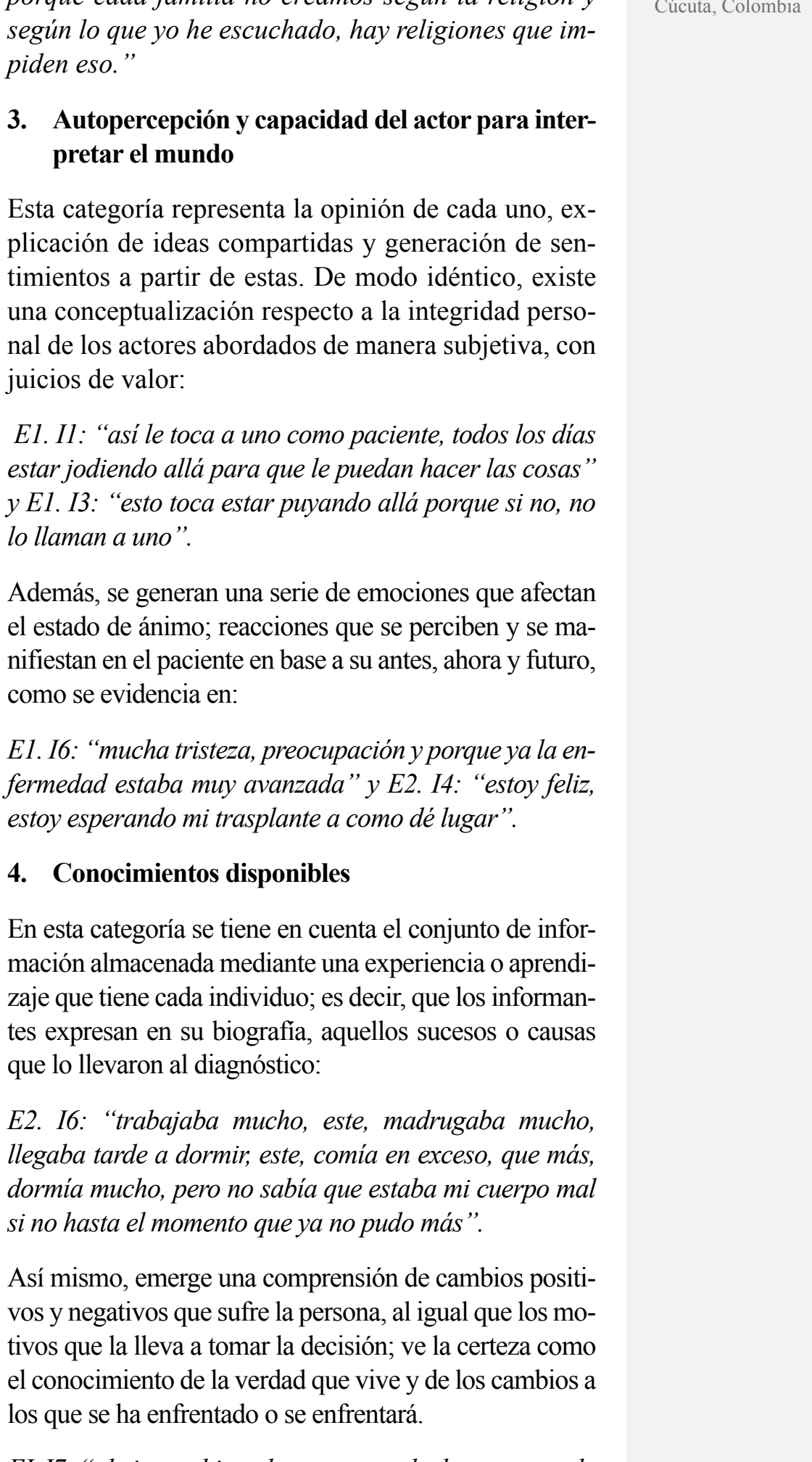

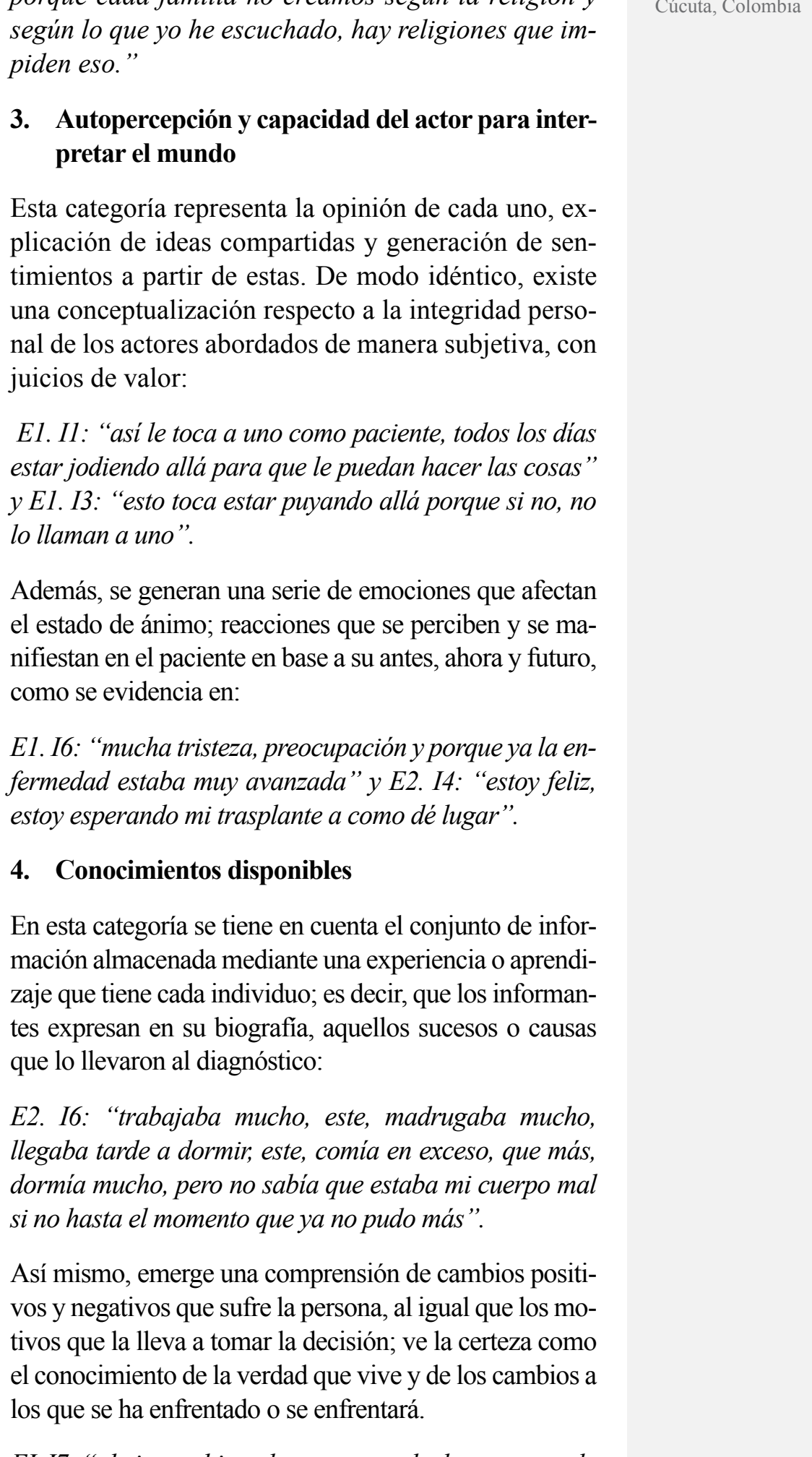

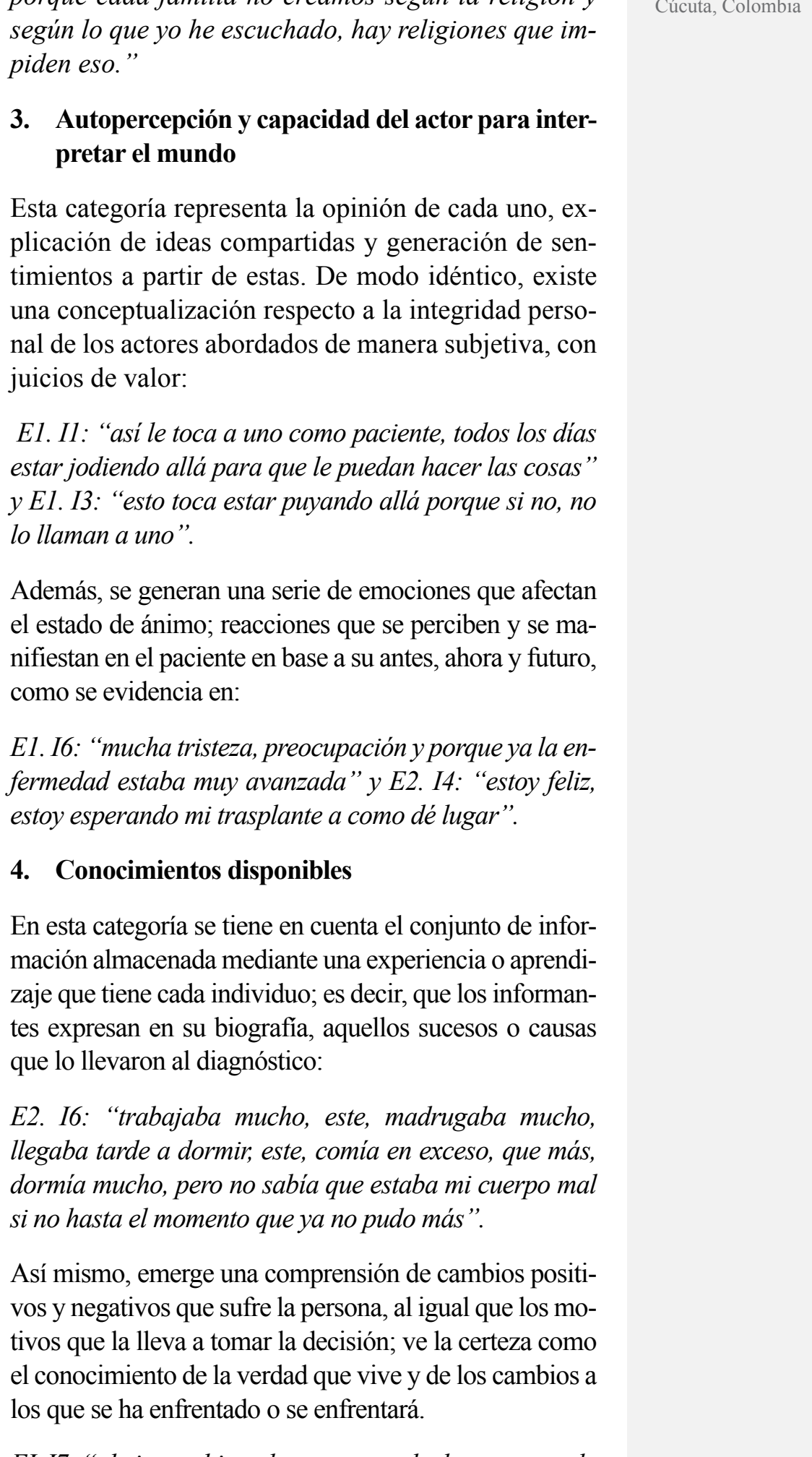

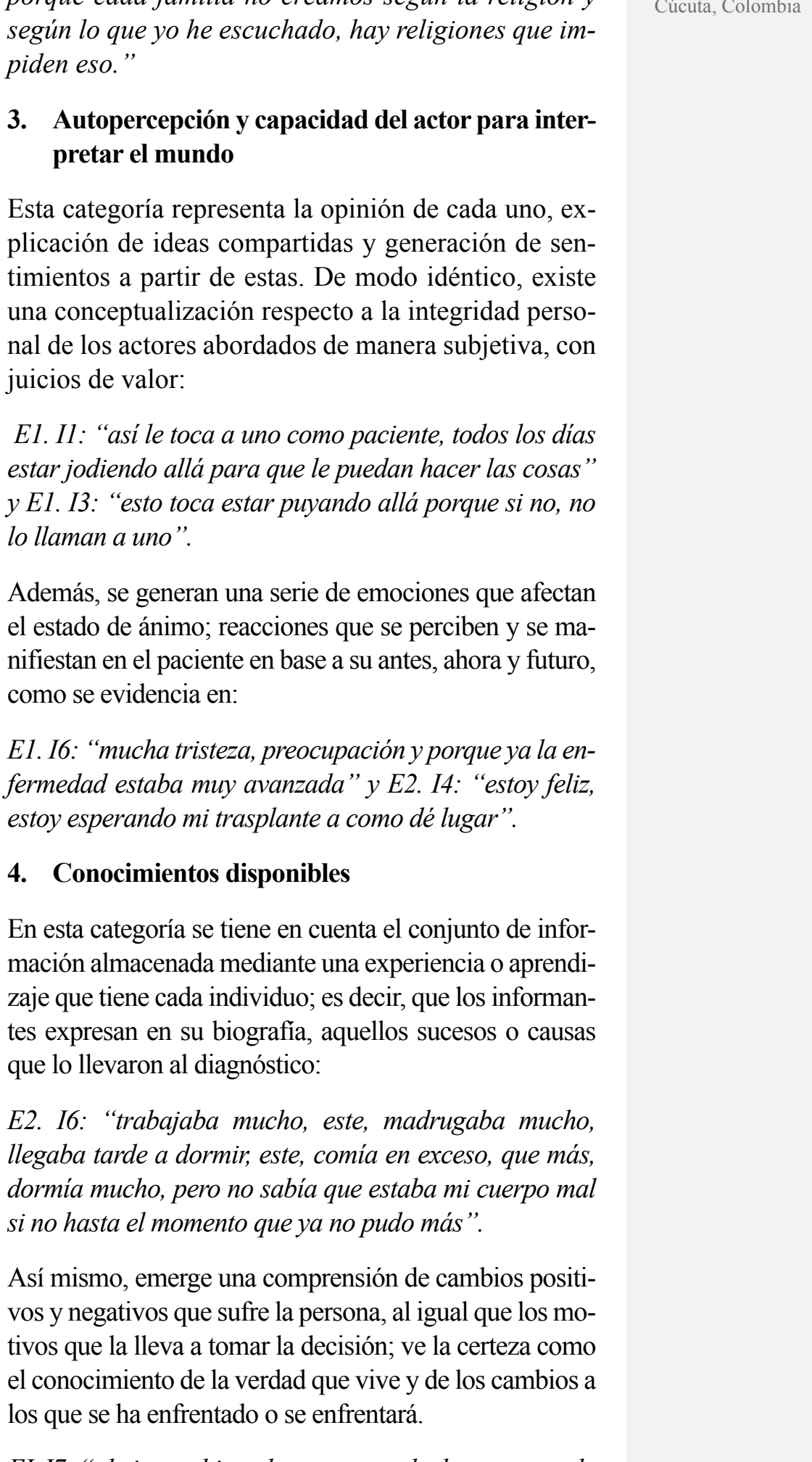

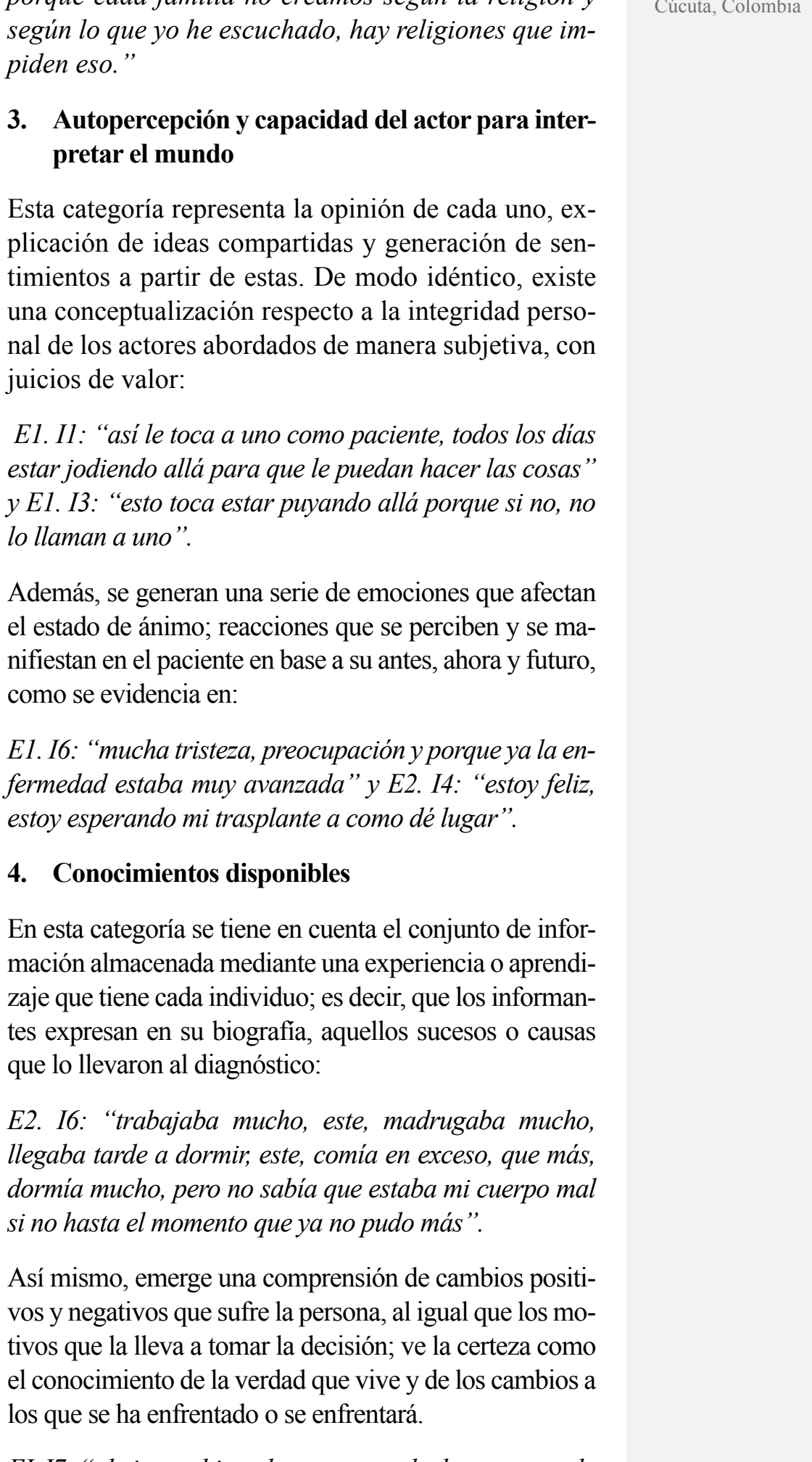

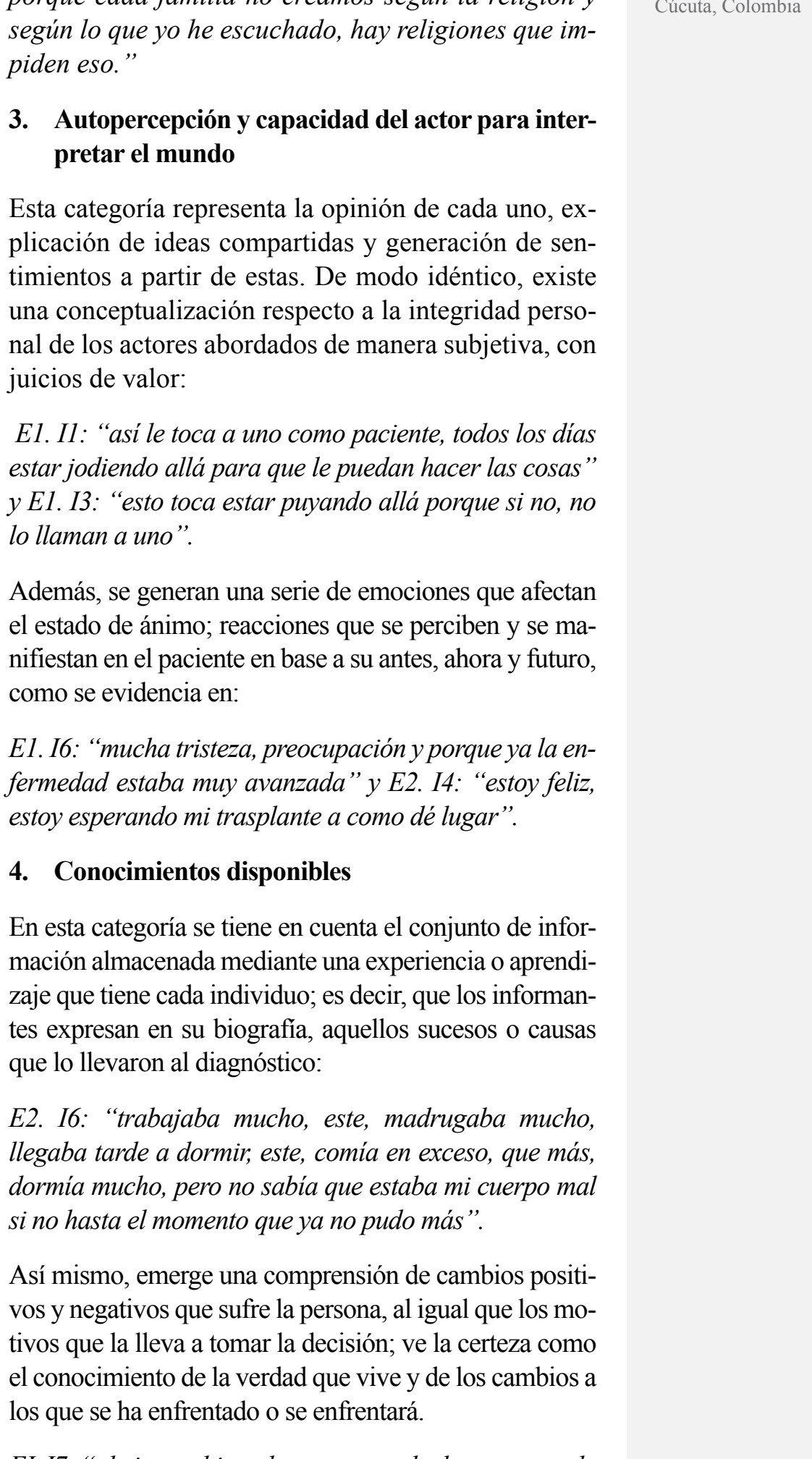

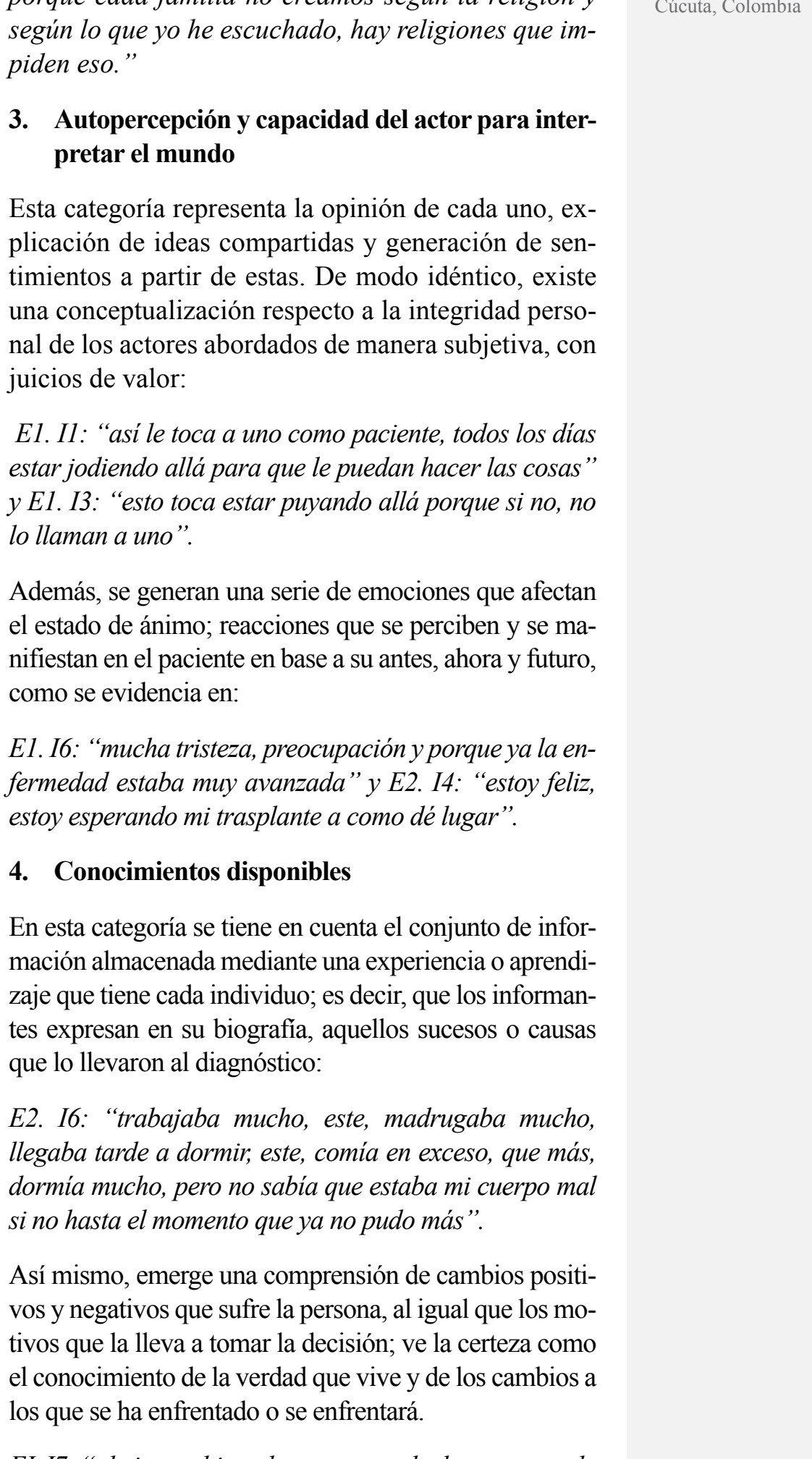

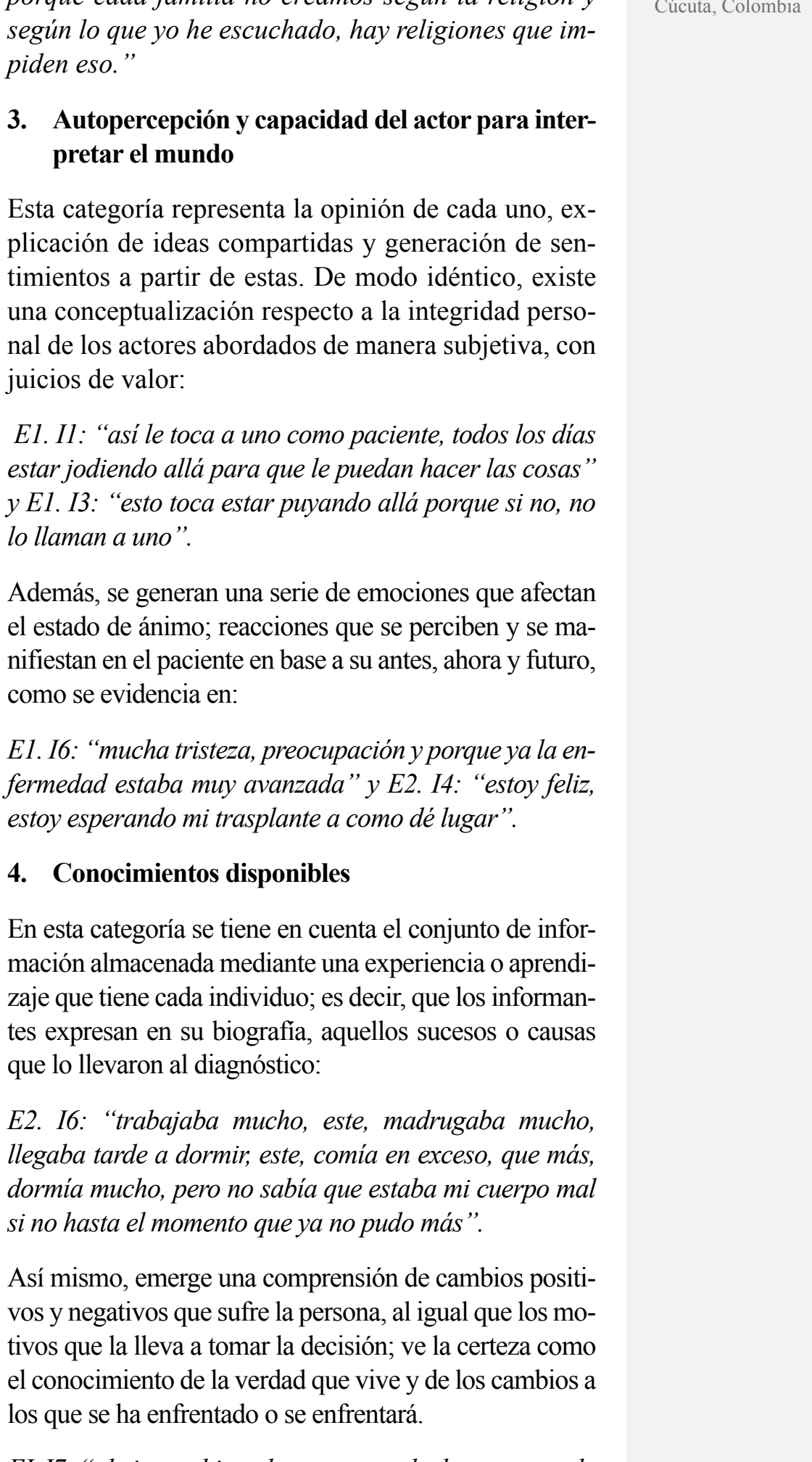

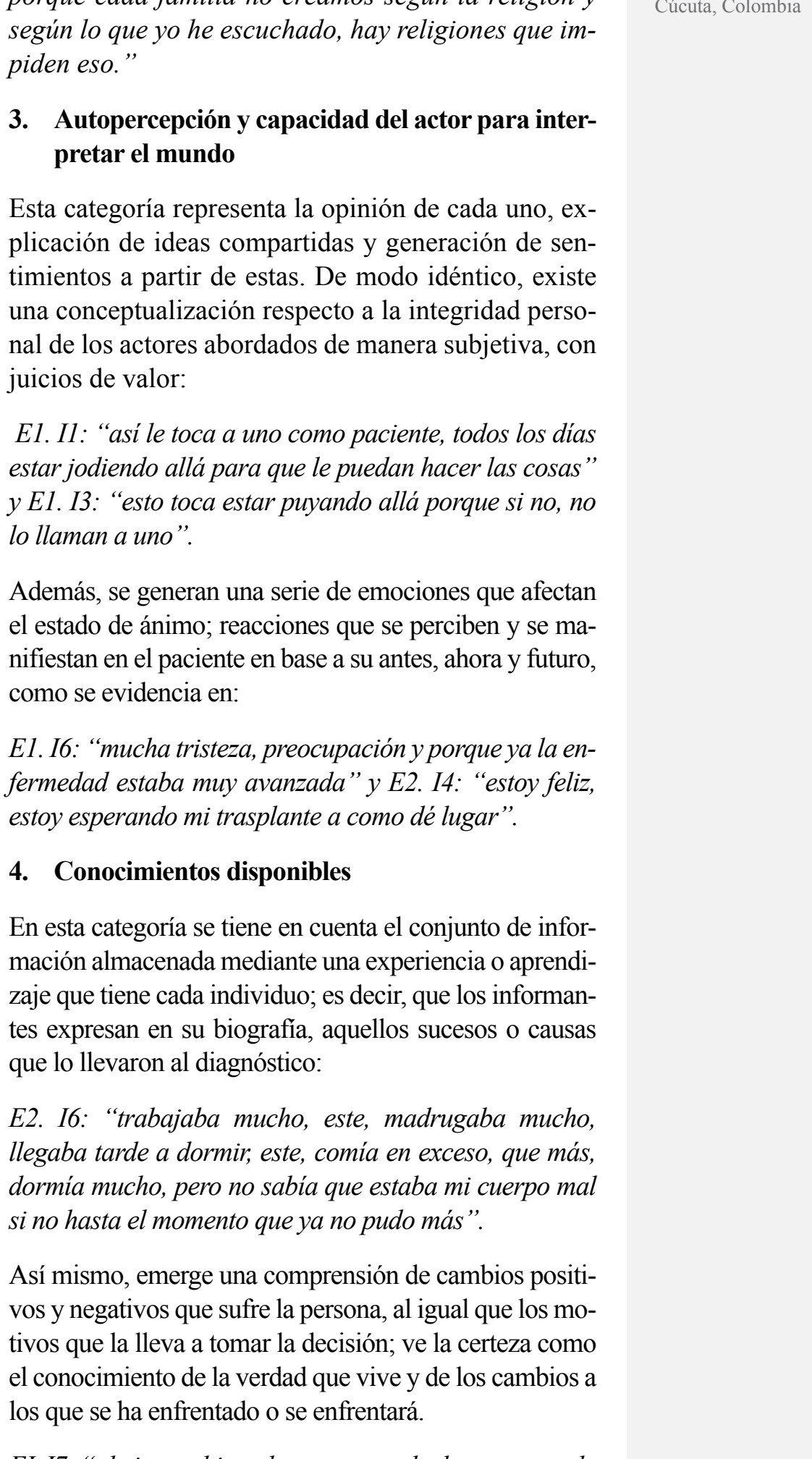

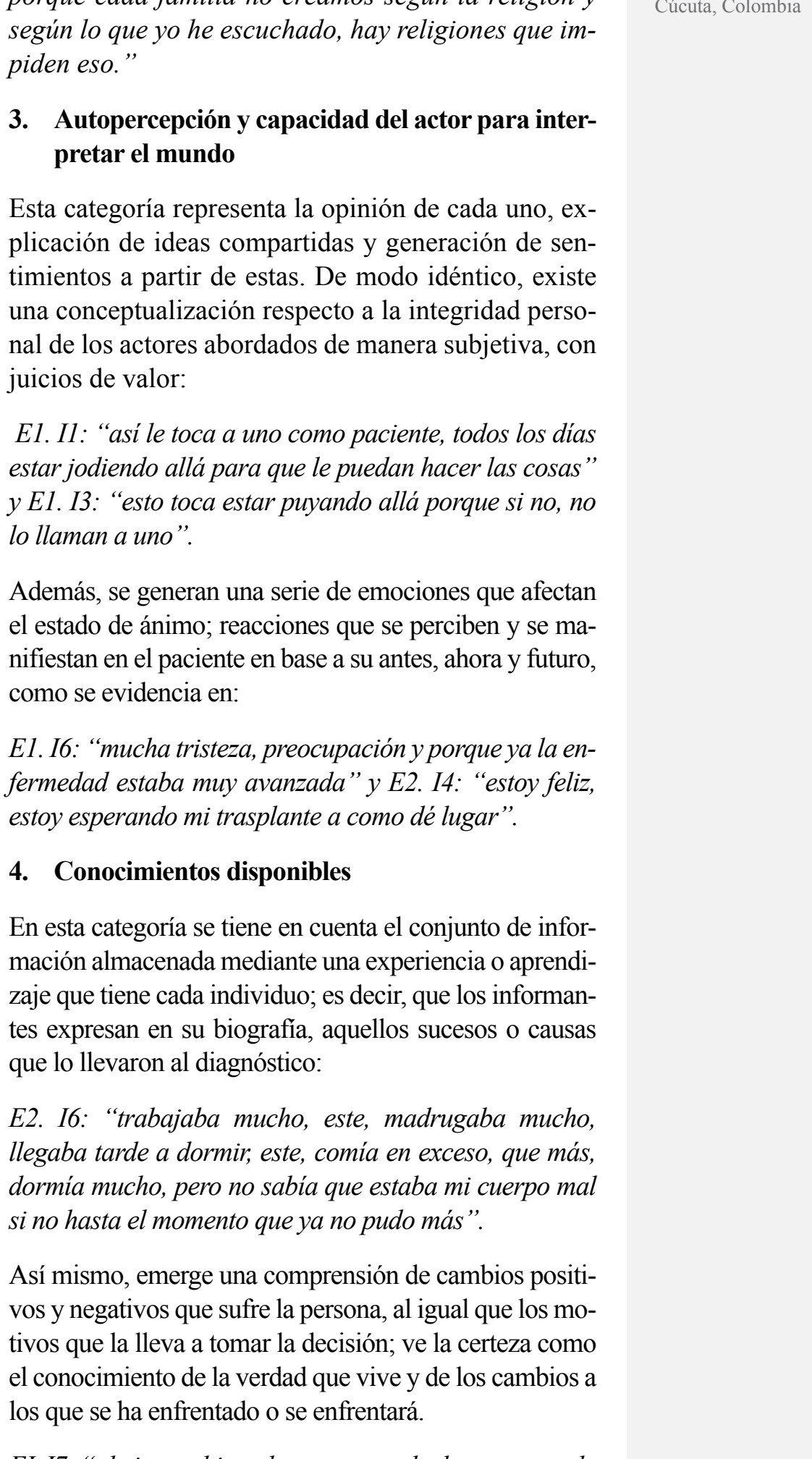

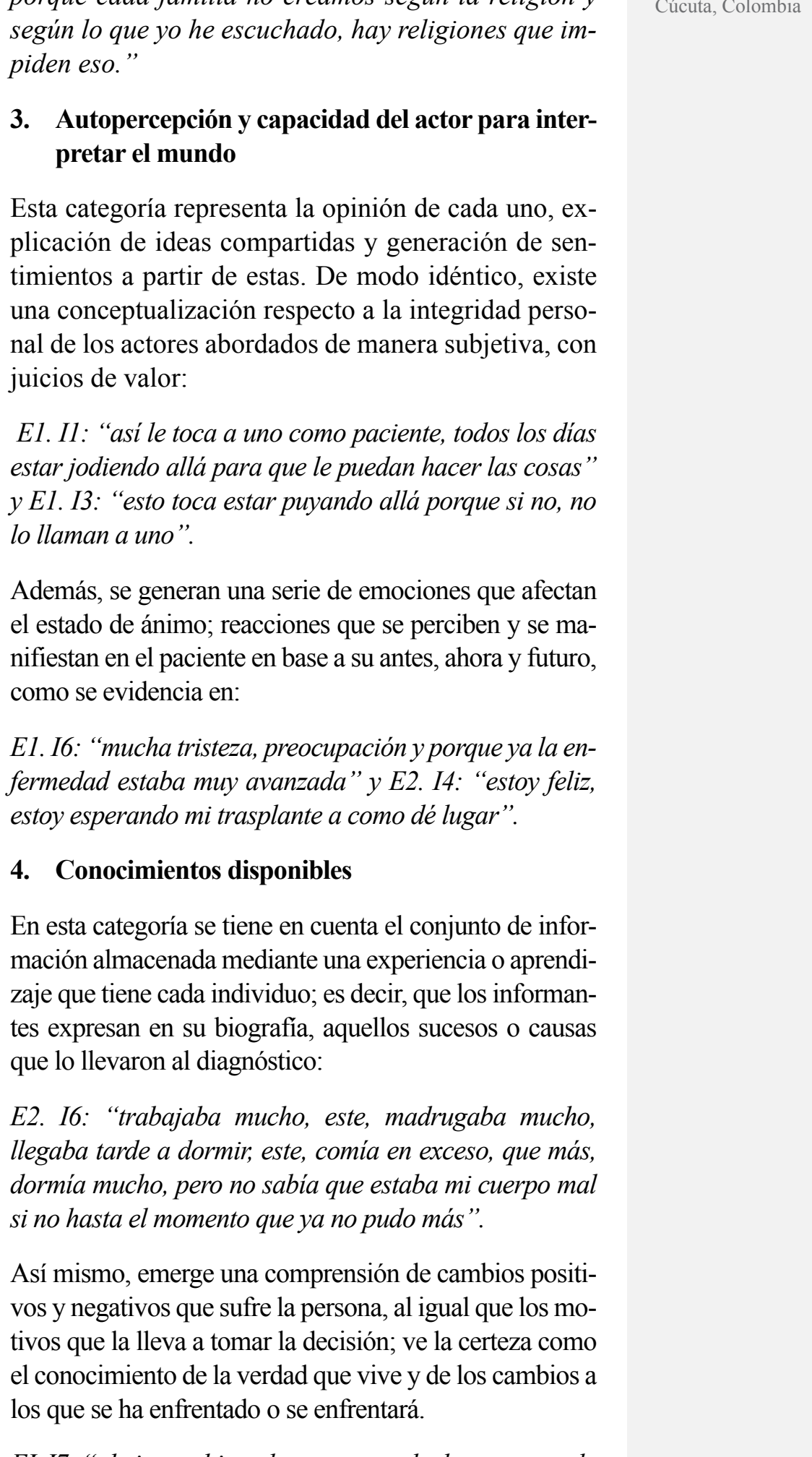

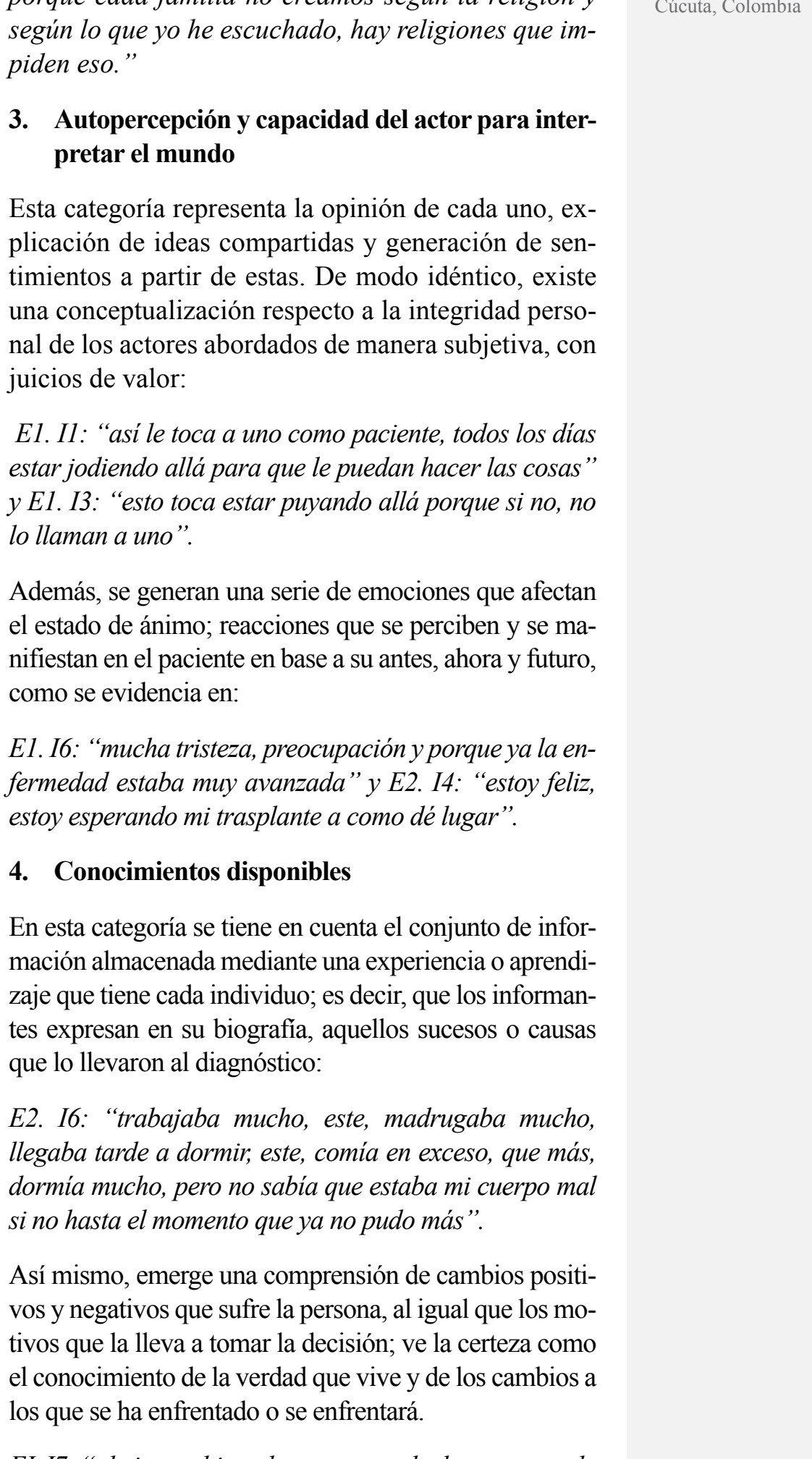

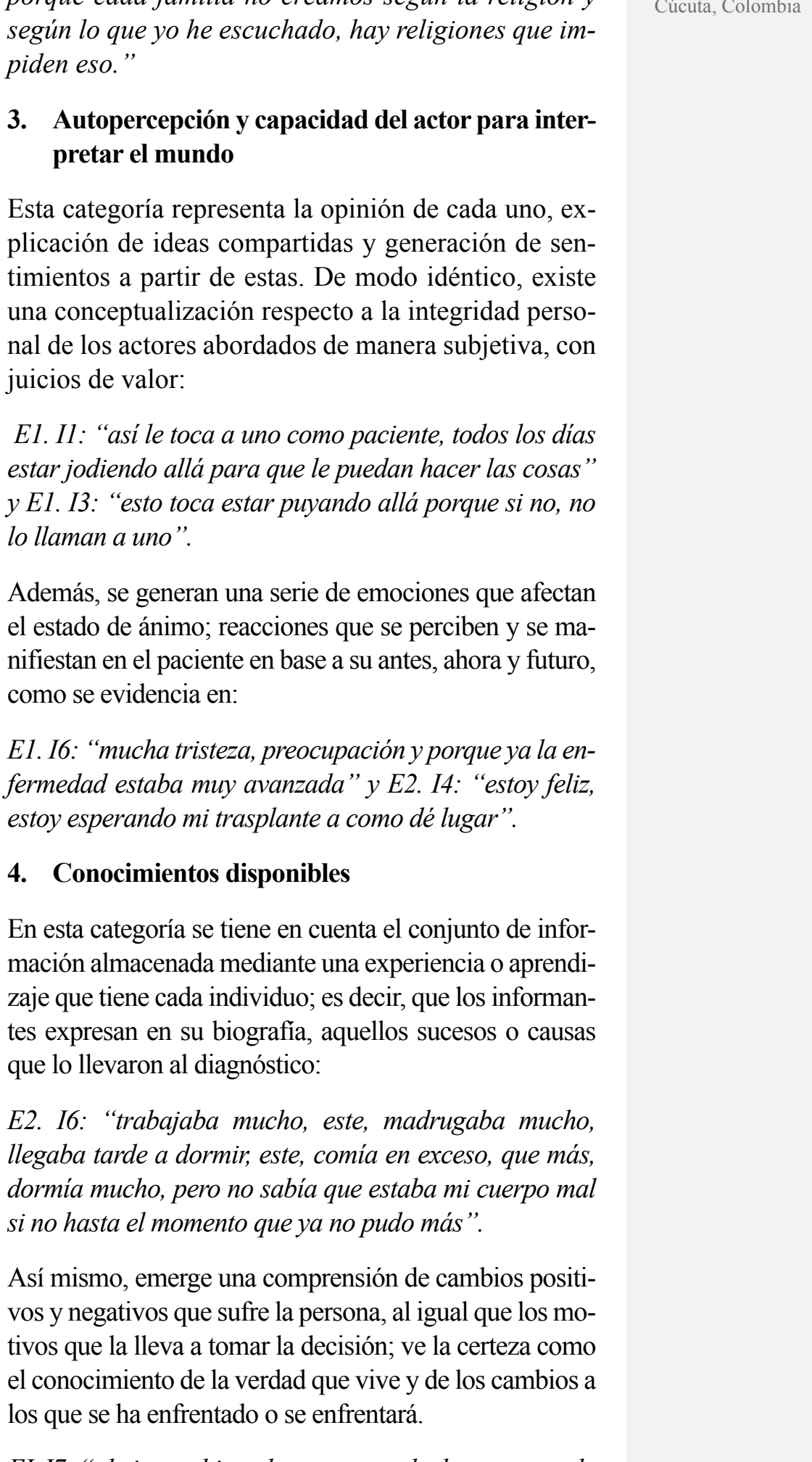

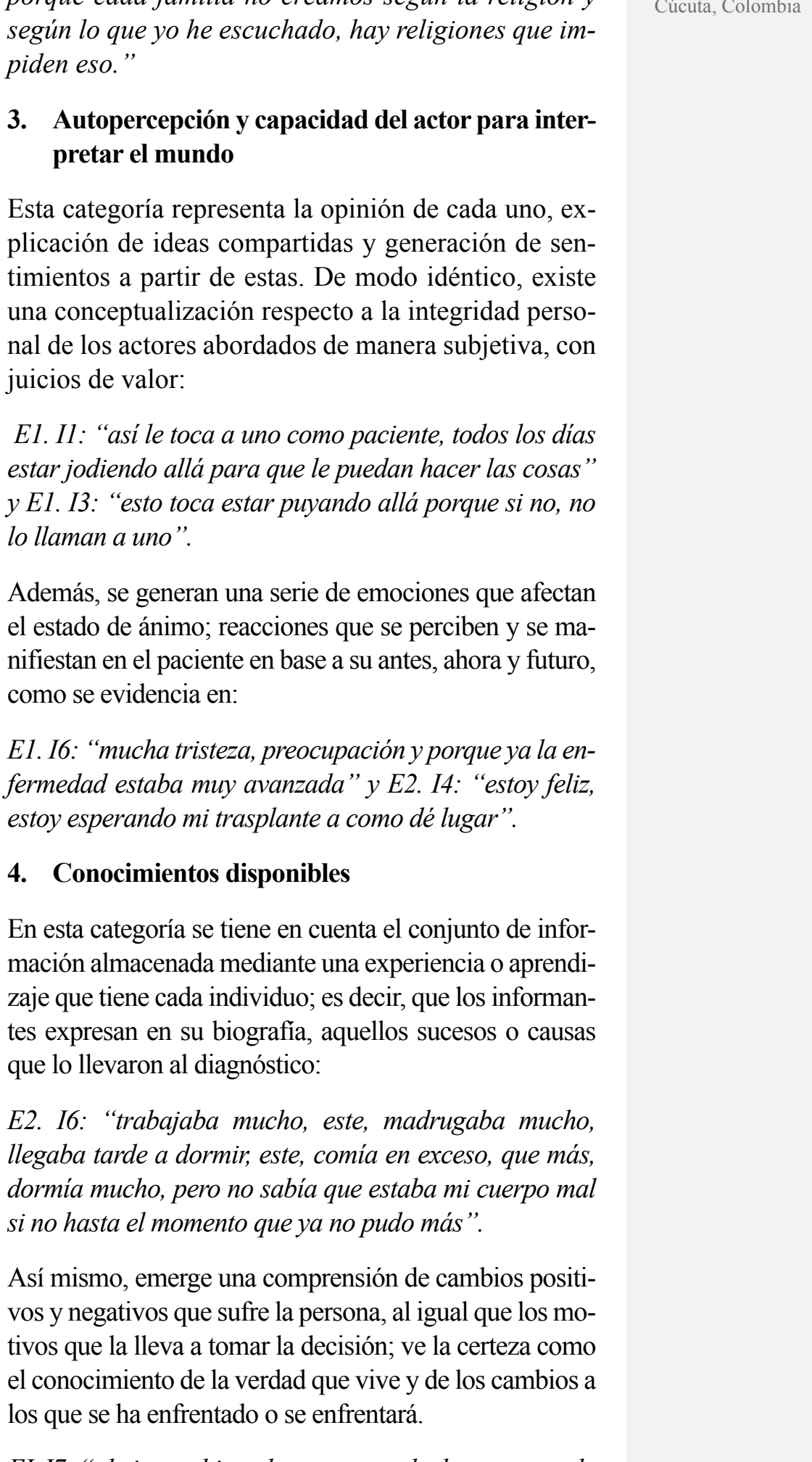

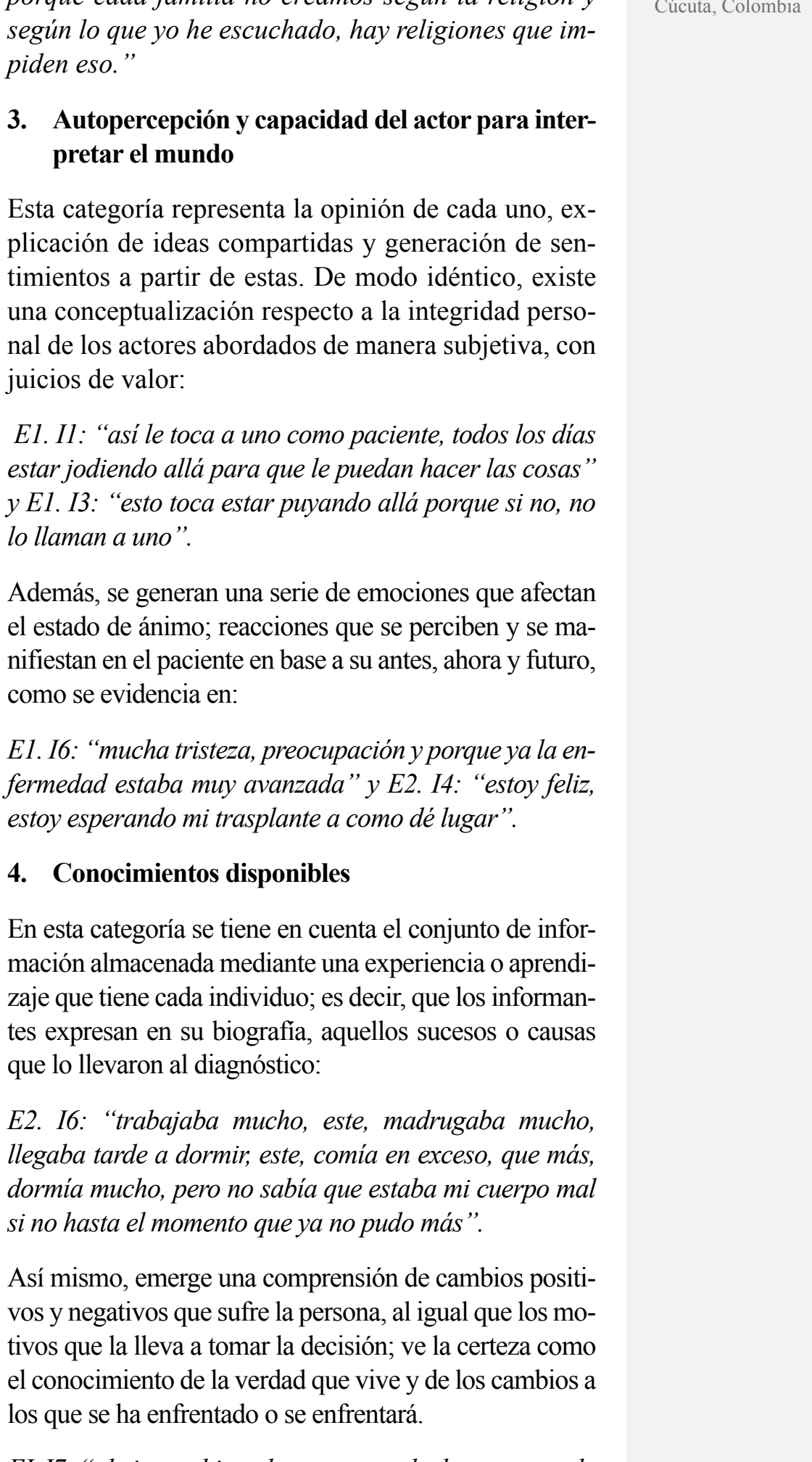

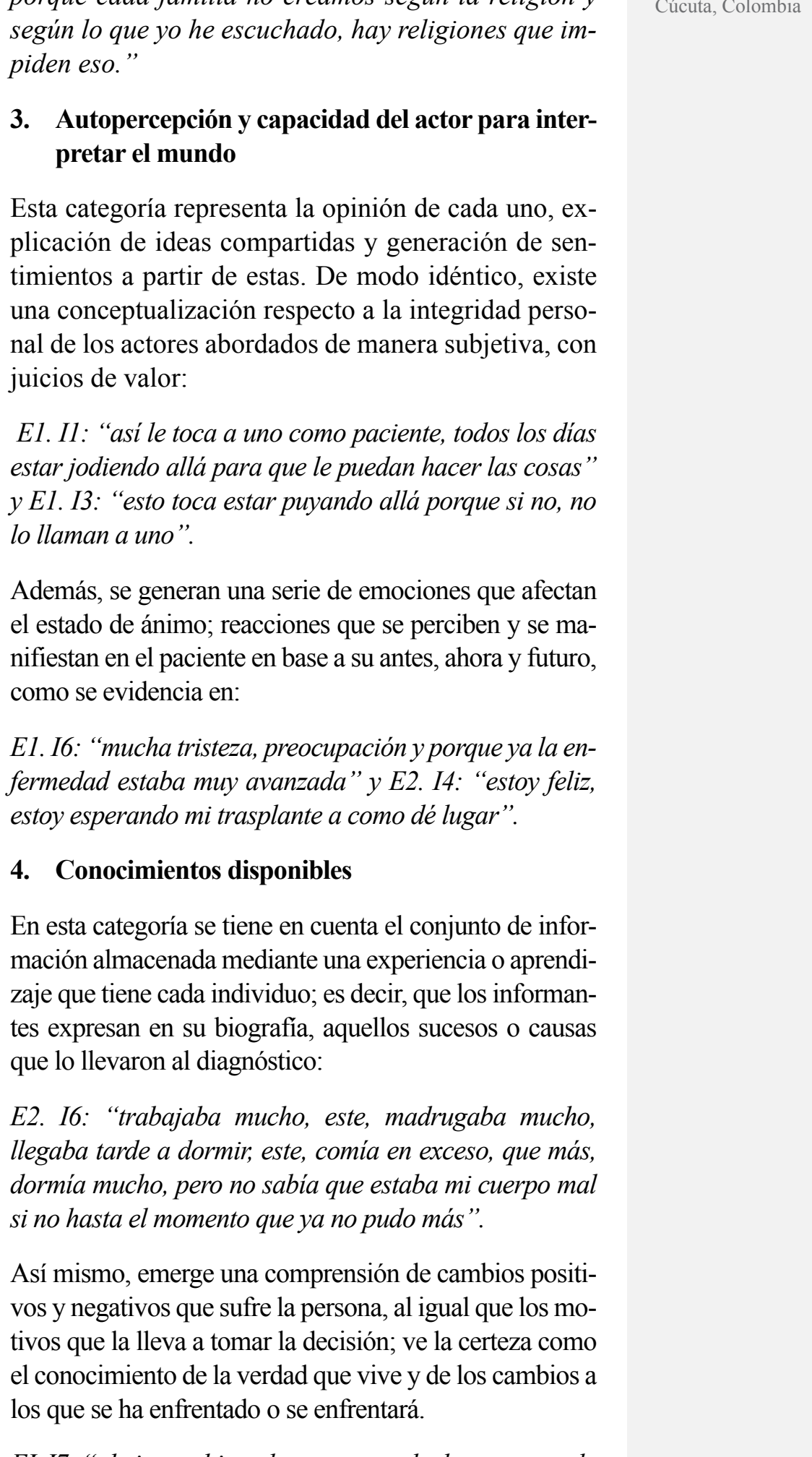

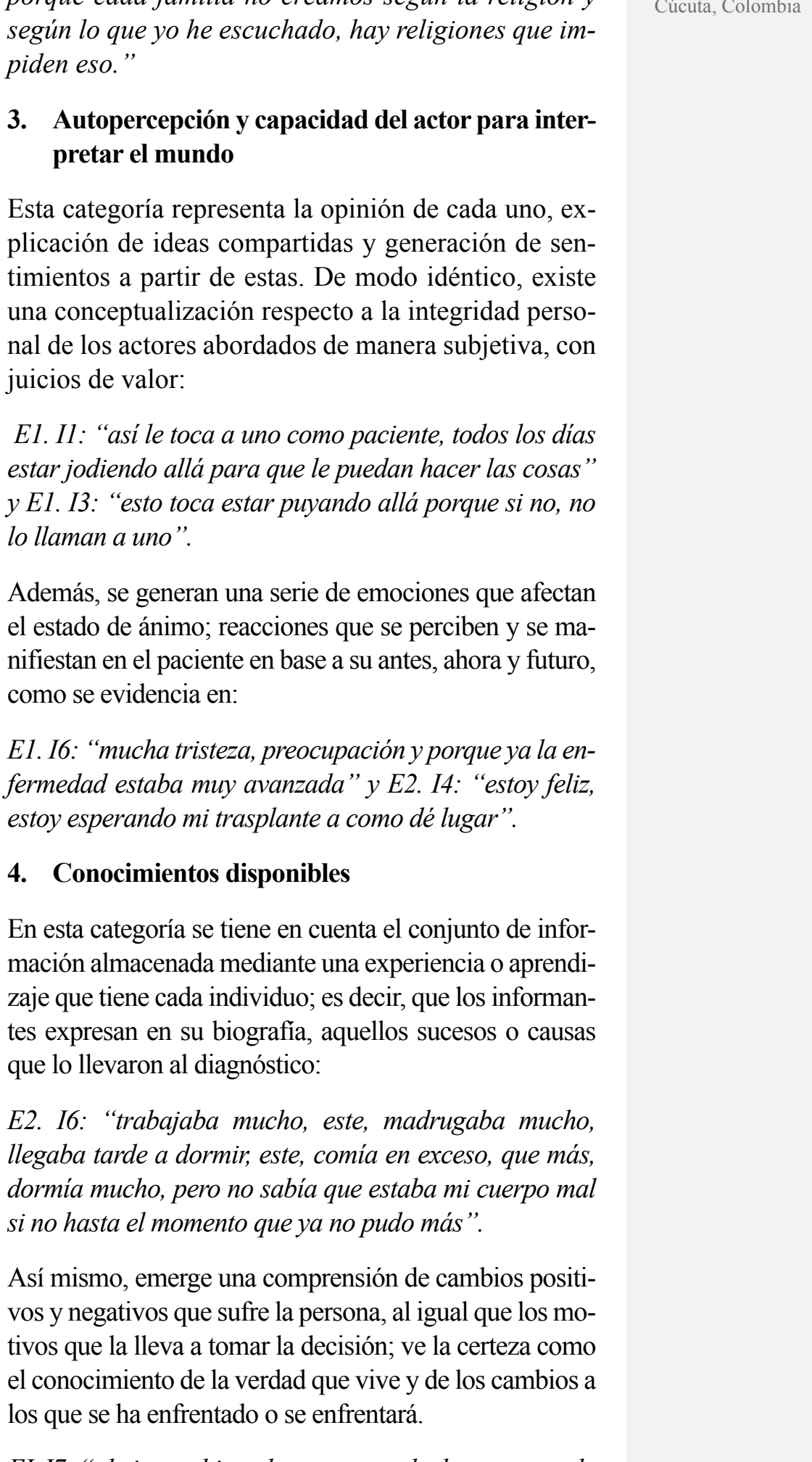

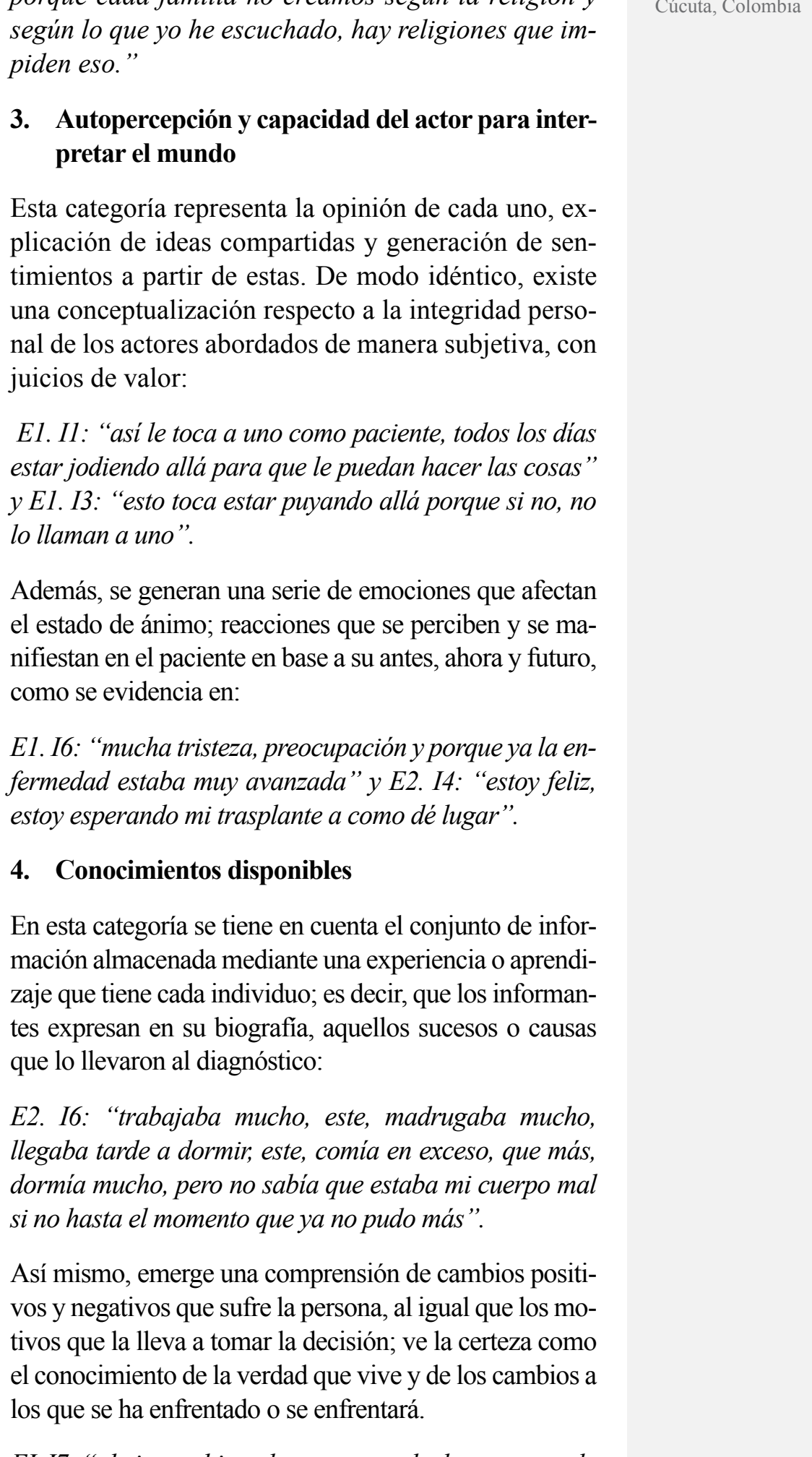

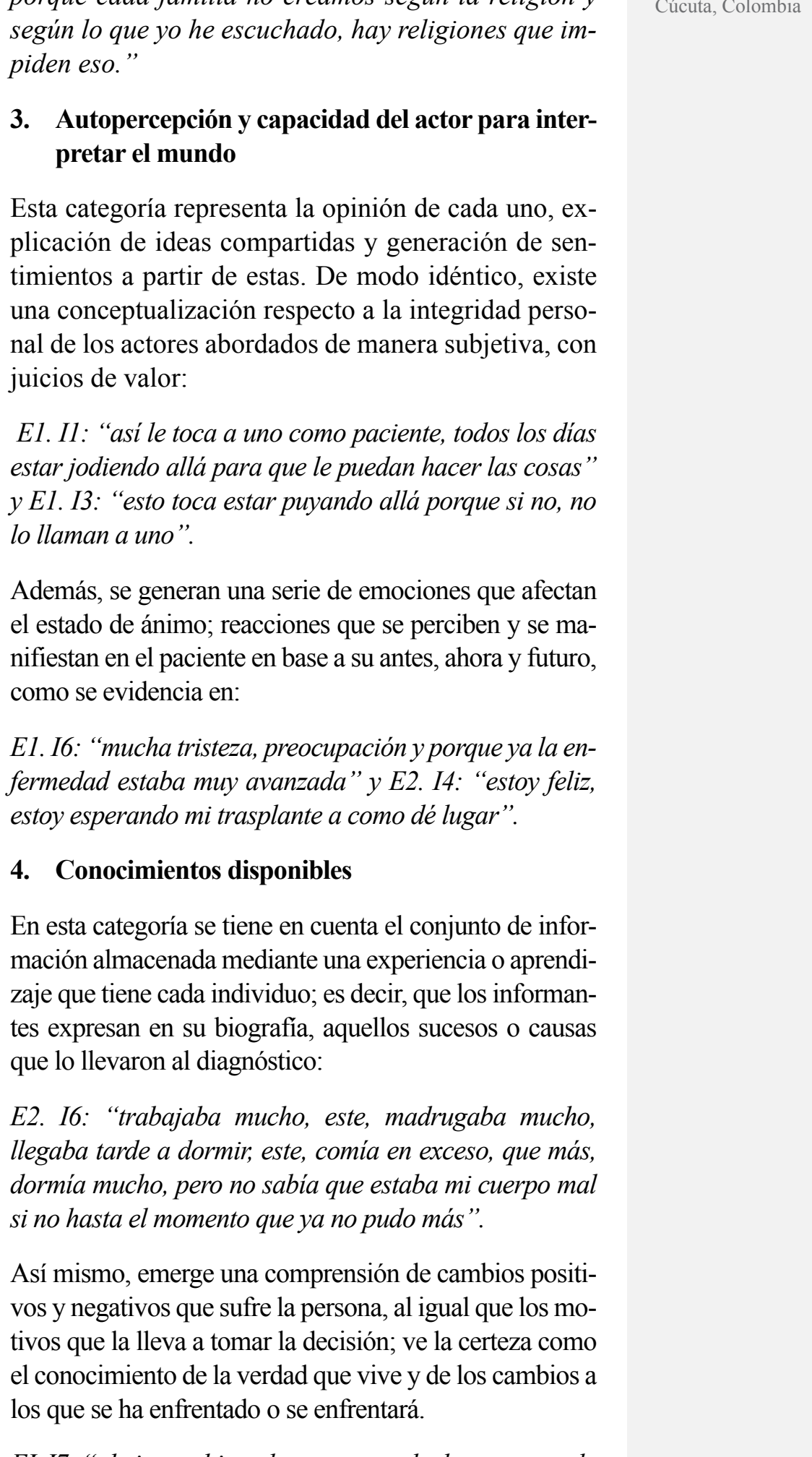

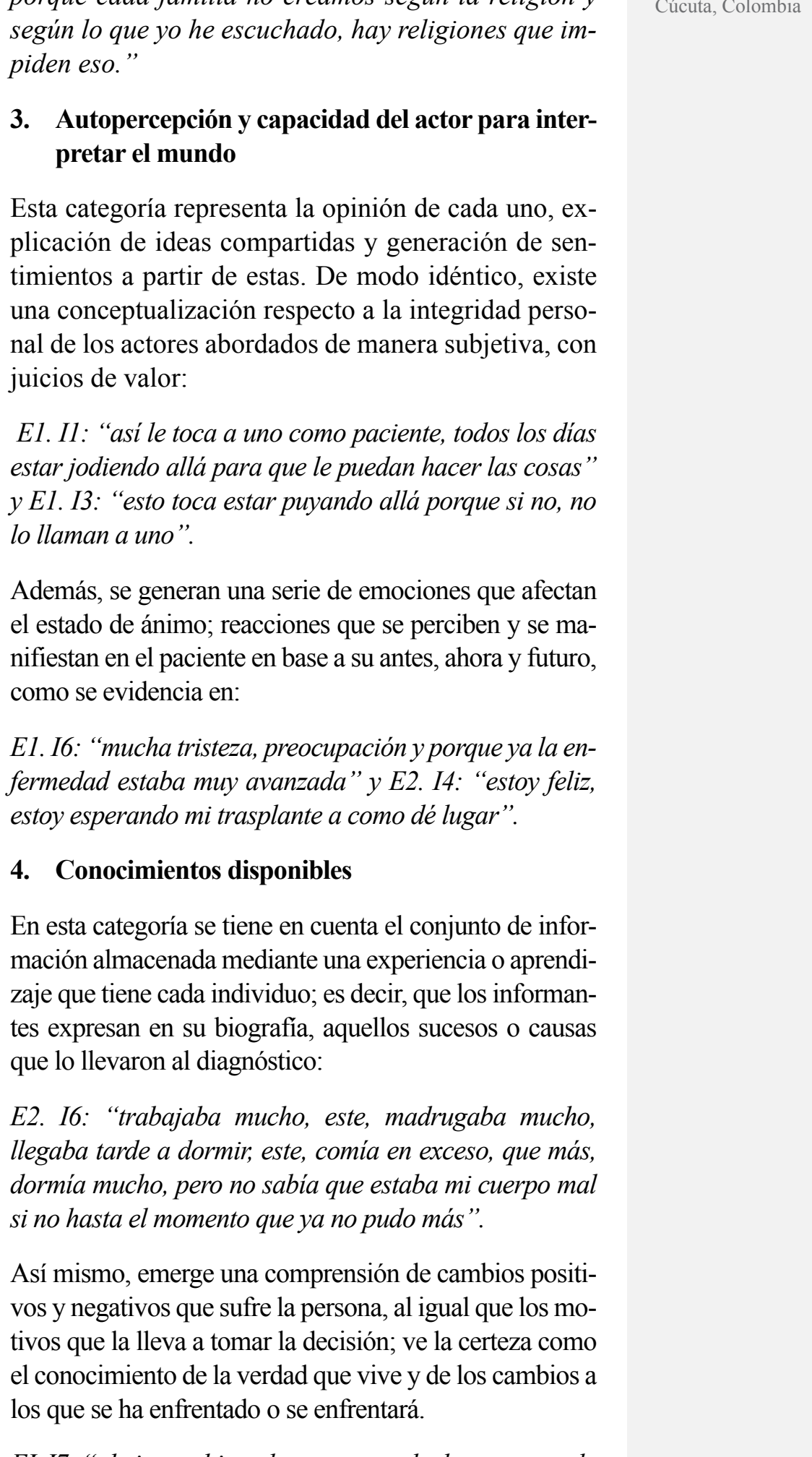

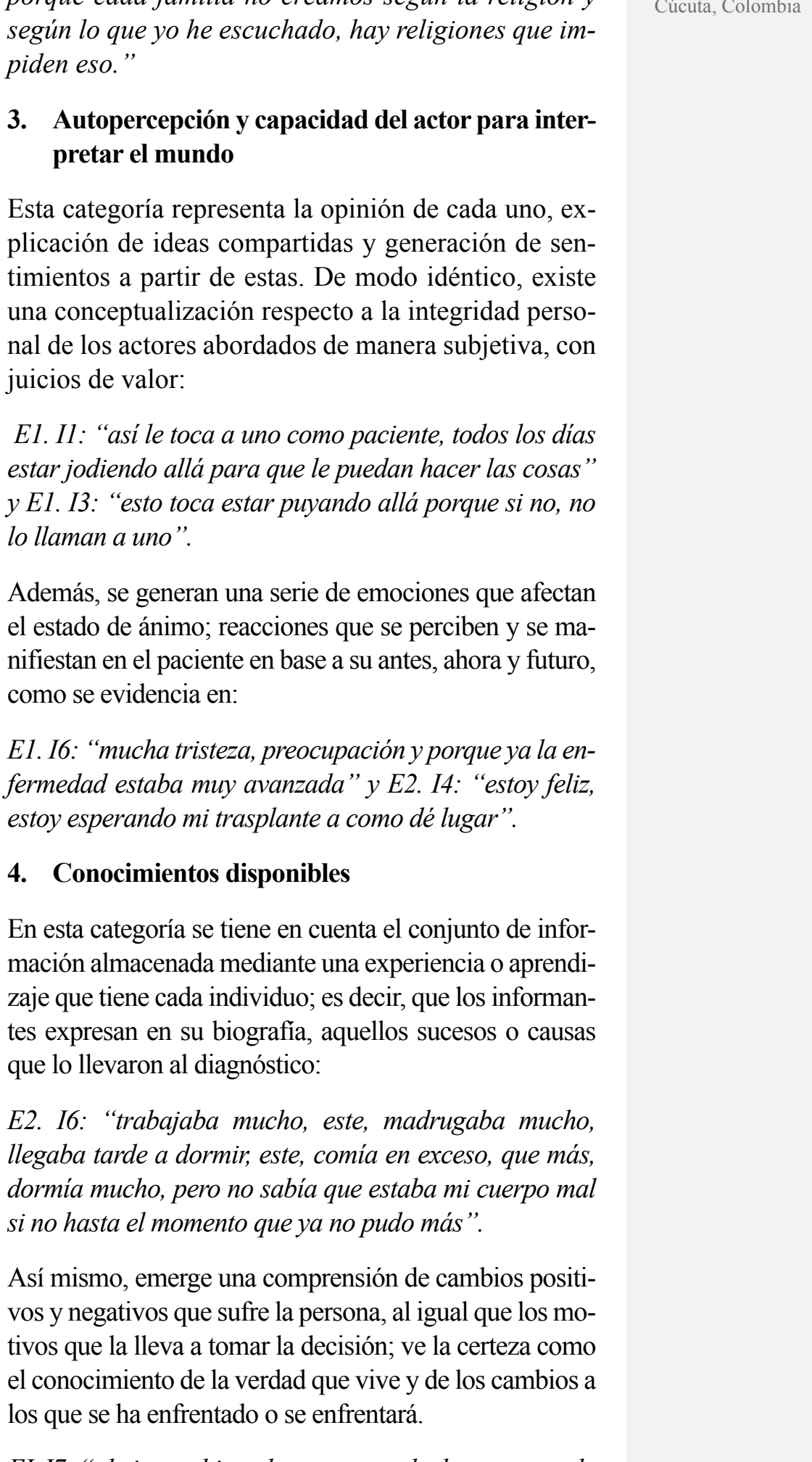

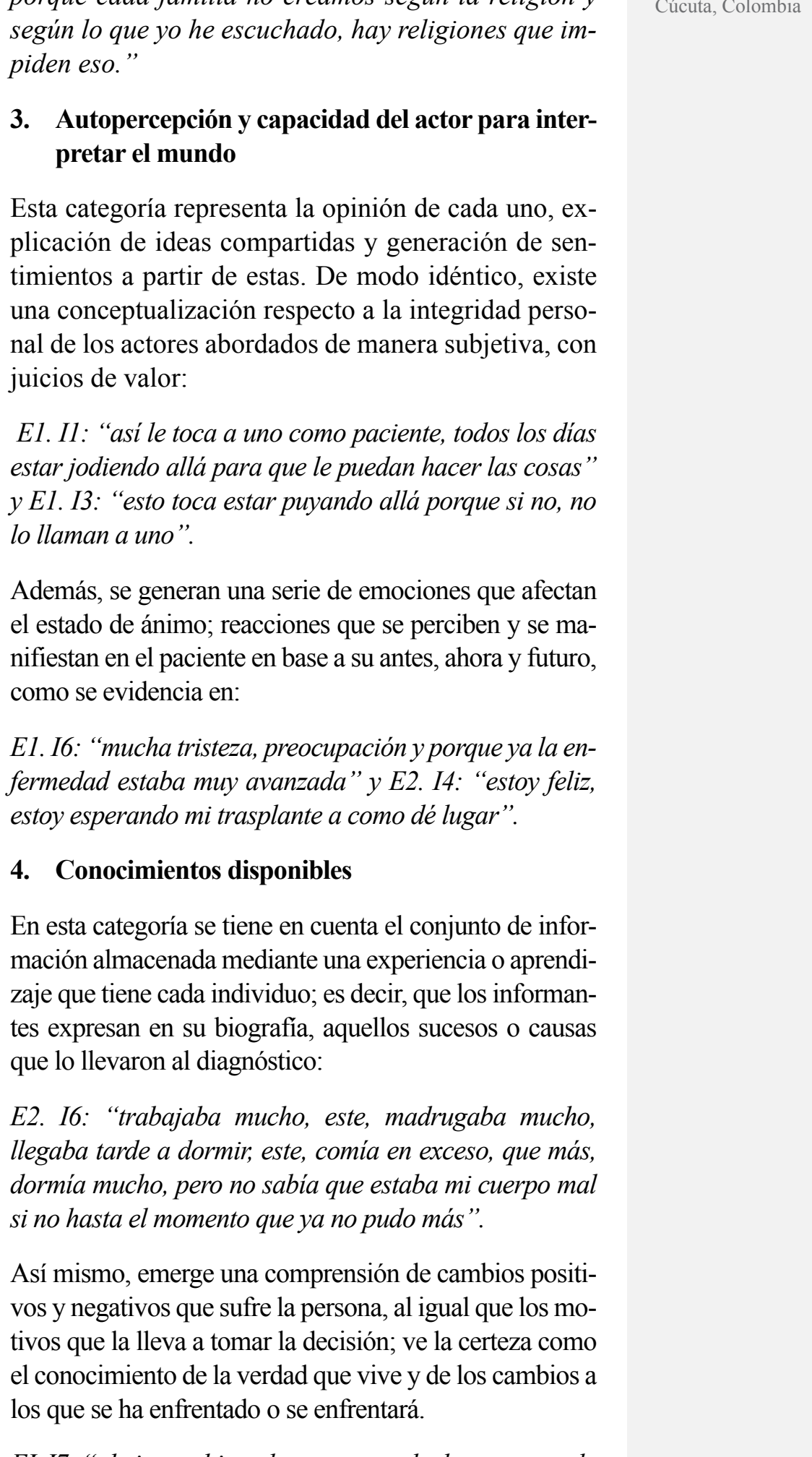

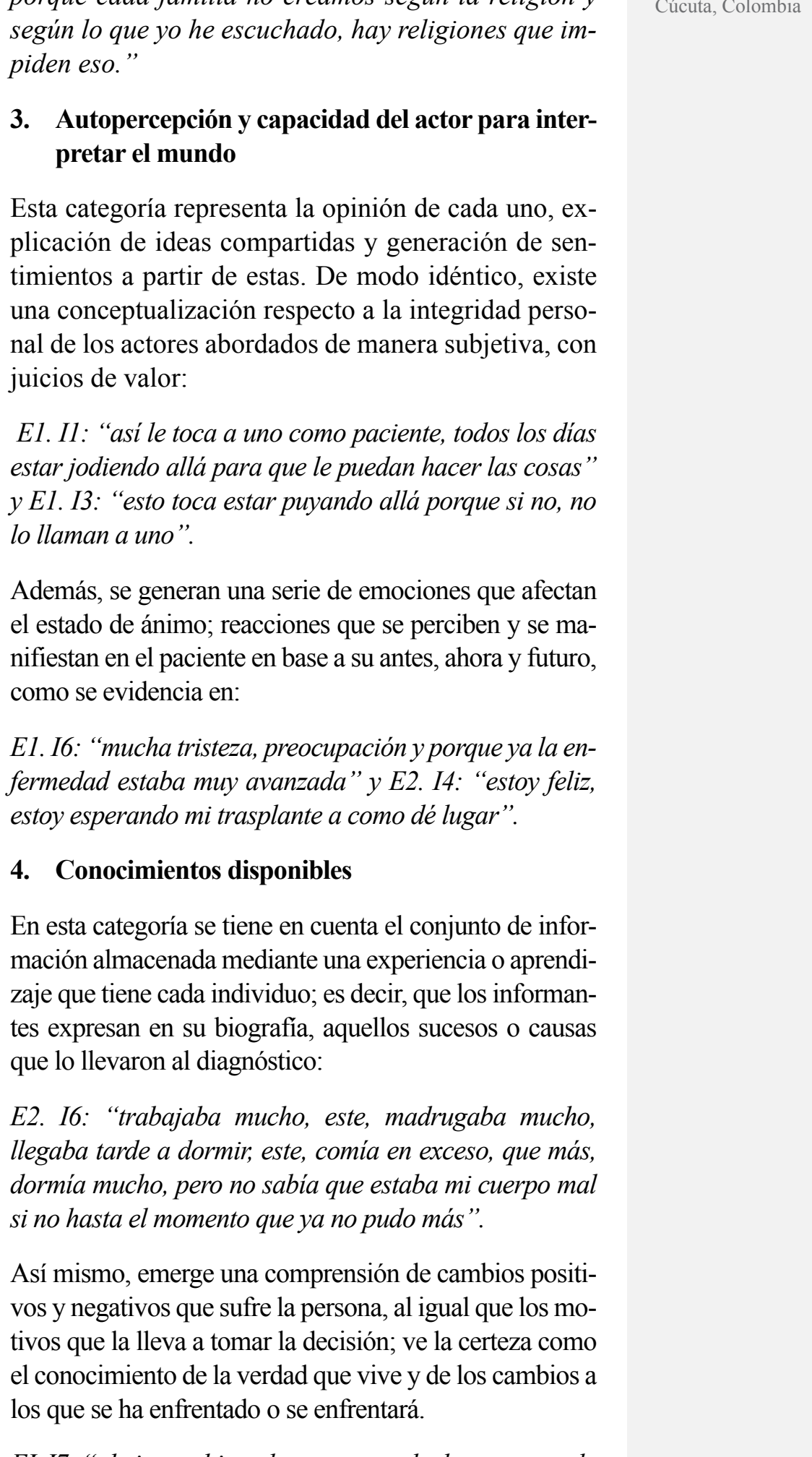

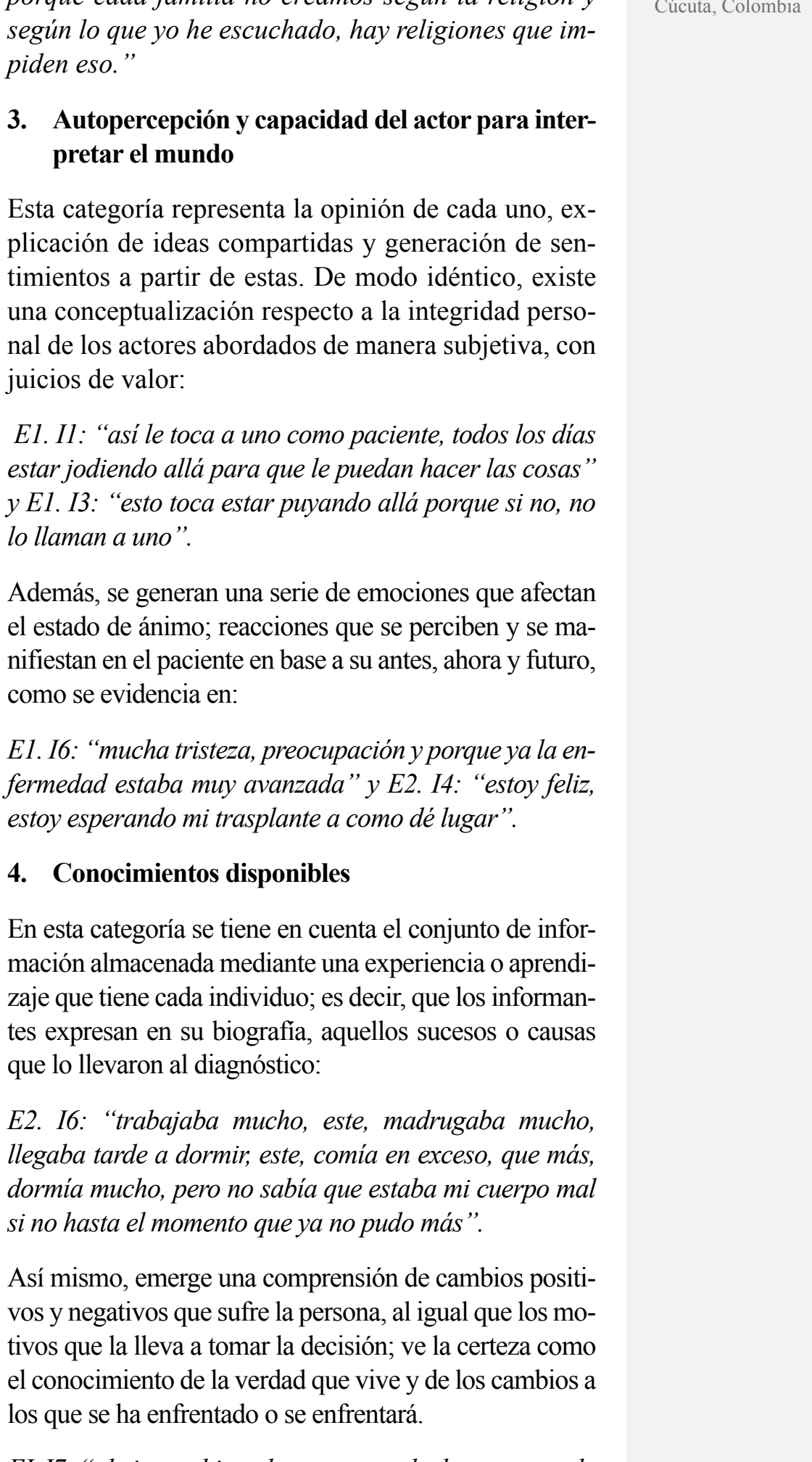

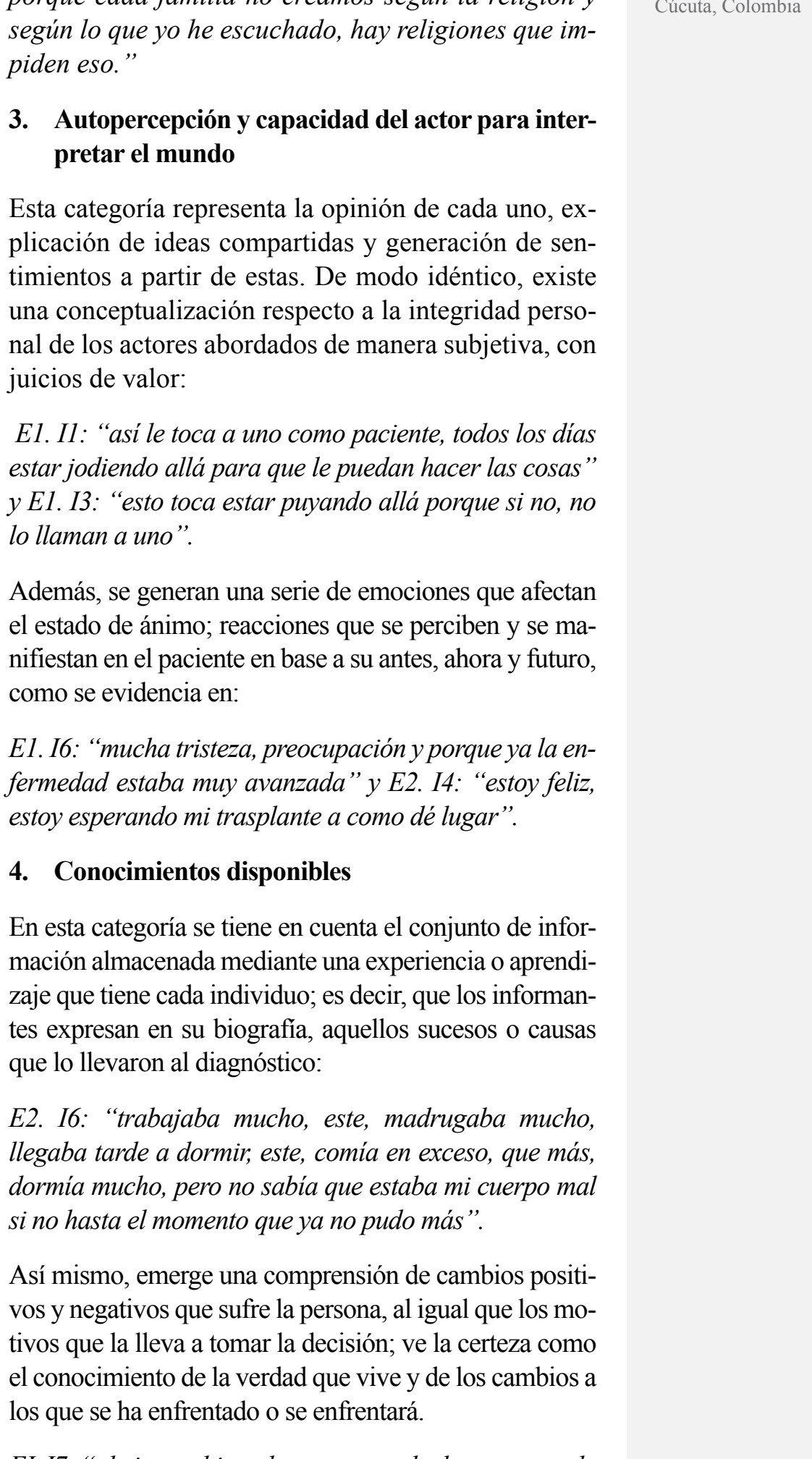

EI. I7: "obvio cambia todo su... su modo de comer, modo alimenticio, todo cambia como para más sano todo más sano... si me entiende y no mejor a mi me gusta". 
ISSN-PRINT

1794-9831

E-ISSN 2322-7028

Vol. 17 No. 2

May - Ago 2020

Cúcuta, Colombia

\section{Implicaciones e impactos sociales}

Los pacientes diagnosticados con enfermedad renal crónica, conocen las implicaciones que esta ha traído a su vida, al relatar su experiencia y lo que representa actualmente su tratamiento. Esto se puede evidenciar:

E2. I7: "que significado Jumm todo (risas) eso es lo que le da vida a uno mejor dicho lo mantiene a uno bien no, para mi es excelente la diálisis, sino hubiera existido ese método, mejor dicho, pero eso si unn es algo para bien, para bien porque te mantiene, te mantiene bien uyy si lo hace con juicio hay esta por largo tiempo".

El apoyo social en el proceso de afrontamiento es percibido a través del apoyo familiar, de amigos, religioso y entes de salud.

E2. I6: "sin la familia uno no logra salir adelante, si, si es muy valeroso eso que estén llamando lo o preguntando por uno, ayudando lo, dando le motivos, este, dando le fuerzas y colaborando mucho, si, es lo principal para una persona enferma la familia".

\section{Mejora de la calidad de vida}

Esta categoría habla de aquellos nuevos estilos de vida y expectativas a futuro; es lo que el trasplante representa en los pacientes y como tal, se lo considera como una opción para evitar la dependencia de la diálisis.
E1. I5: "la máquina que nos ponen para dializar ella nos saca todo lo bueno y lo malo entonces uno, yo llego aqui a mi casa cansada, cansada completamente cansada...".

Sin embargo, el trasplante se vislumbra por los participantes como una nueva oportunidad de vida, que da fin a la terapia de diálisis, aunque ese primer momento de abordaje del tema desencadena en un choque de sentimientos:

E2. I5: "Que significa pues imagínese otra oportunidad de vida aún mejor porque yo eh escuchado que si nos operan y nos dan un riñón nuevo pues vamos a, a como esa ya no nos van a dializar más y ya podemos trabajar, ya podemos comer ya más cosas tomar más líquido".

Los pacientes en lista de espera para trasplante argumentan que es necesaria la sensibilización y educación de la población en torno al tema.

E1. I6: "porque falta más información, educar más las personas, informarles más acerca de las vidas que se pueden salvar, porque no estamos conscientes de eso si no hasta el momento que lo necesitamos".

\section{Personal de salud}

Los grupos focales realizados con el personal de salud arrojaron 6 categorías, que se agruparon en 3 familias. Ver Tabla 2.

Tabla 2. Clasificación de categorías en personal de salud.

\begin{tabular}{lc}
\hline \multicolumn{1}{c}{ Categorías } & Familias \\
\hline Principios Bioéticos & DILEMAS Y JUSTICIA \\
Justicia Distributiva & SANITARIA \\
Proceso de Donación & LA EDUCACIÓN AL \\
Apoyo Interdisciplinar & PERSONAL DE SALUD Y \\
Moralidad en la Ética del Trasplante & ELESIDAD DE FORTALECER \\
Sensibilización & HUMANIZ DE LA BIOÉTICA \\
\hline
\end{tabular}

Fuente: Autores.

\section{Dilemas y justicia sanitaria}

Esta categoría está relacionada con las situaciones que ponen en duda al personal de salud, en la que la ley 1805/2016 es un factor importante. El tema de justicia distributiva el personal lo posiciona dentro de las iniciativas legales, de las cuales se pueden aprovechar las modificaciones realizadas a la norma, para aplicarla a su práctica clínica, tal como lo manifiesta:

GF114: "Puede ser más como un respaldo, o sea algo que tenemos... como una carta bajo la manga...eeh tenemos... eso como que ayuda a eliminar un poco los tabú de la gente". 
Pero hay ciertas consideraciones respecto a cómo se dio la inclusión de la ley a la población,

GF116: "no basta con implementar una ley e imponer algo obligatorio si no hay una educación respecto al porqué se toma esa... esa medida”.

Ahora bien, a nivel personal se presentan una serie de dilemas con relación a la norma, pues consideran una situación difícil de enfrentar por parte de los familiares.

GF. 113: "yo creo que el hecho de que la familia lo conociera a uno como el personal que estuvo presente durante el proceso de enfermedad de su familiar, va a ser más dificil que sea ese mismo personal sea el que le diga "su paciente o su familiar es un posible donante...".

El hecho de presentarse hipotéticamente una situación similar a la de los pacientes en espera, se evidencia que no hay pleno convencimiento sobre la aceptación de la donación,

GF3I1: "yo hablo por mi si quieren sustraer mis órganos no tengo ningún problema pero que ya sea un nieto o algo me lo pensaría y me valdría que otras personas sean beneficiadas o no".

Adicionalmente, el tema de la donación se ve enmarcado por la bioética, que hace que surjan todo tipo de juicios y actitudes no solo por la norma, sino también por los principios de autonomía, beneficencia y no maleficencia, tal como se verbaliza,

GF1I4: "Yo si lo tuve allá en Bucaramanga, un paciente este... el muchacho era fisioterapeuta y había tenido un accidente en una moto, pero él ya había firmado lo de donación de órganos"

A nivel personal, los profesionales manifestaron la aplicación de principios bioéticos, entre los cuales se resaltan la beneficencia, autonomía, no maleficencia y justicia, tal como lo manifiesta,

GF2I1: "de mi pueden salvar 5 o 6 vidas de los órganos de los que yo tengo para donar, para mi significa eso salvar más vidas y darle otra oportunidad a otra persona de que siga, ya que pues en mi pues no se puede continuar la vida"

\section{La educación al personal de salud y necesidad de fortalecer el estudio de la bioética}

La extracción de órganos exige una rápida intervención y actuación coordinada por un equipo interdisciplinar. El proceso de rescate es una carrera contra reloj que necesita coordinación y cuidado.

GF113: "no solamente aceptar lograr que el familiar acepte, cumplir todos los requisitos del donante si no conseguir ese receptor que cumpla las características para que sea un buen receptor, todo es un proceso bastante complicado...".

Entre tanto, el personal desconoce a fondo la distribución de los órganos.

GF3I3: "es que la verdad como nosotros no tenemos claro, como es que toman las decisiones, nosotros sabemos que se llevaron los órganos, pero cómo tomaron la decisión, a quien se los daba... nosotros no sabemos nada de eso".

Del mismo modo, el personal manifiesta que es indispensable la cooperación multidisciplinar para el éxito del proceso, aun cuando son conscientes de que su papel es limitado.

GF. 113: "el proceso que hay, nosotras simplemente hacemos la activación de la alarma...como decía Gina, ya no somos parte como tal de proceso hablando directamente con la familia ... pero si iniciamos un proceso haciendo una alerta de ese posible donante..."

\section{Humanización del proceso}

El personal de enfermería y médico se enfrenta a diversas confrontaciones éticas o de principios, dado que conocen lo bueno o lo correcto frente a las diferentes situaciones que se les presenta que les plantean dilemas.

GF3. I5: "Que querían donar.. pero la familia no aceptó, solamente aceptó dos órganos entonces también esta esa controversia de tanto la familia como la red en ponerse de acuerdo en esa parte".

Los informantes se refieren a la sensibilización, así como a la manera de fomentar en la ciudadanía la toma de consciencia y al análisis de algunos de los problemas que afectan a nuestra sociedad, en este tema de la donación de órganos y trasplantes de tejidos, como una oportunidad de mejora y atribución al bien común de la sociedad.

GF2. I5: "yo diría que, desde la escuela, ... el no tener el temor a tocar estos temas, como decíamos antes de la muerte y más si es de un familiar a todo el mundo le causa miedo...pero si se empieza desde el colegio, desde la universidad a tocar estos temas, yo creo que 
ISSN-PRINT

1794-9831

E-ISSN 2322-7028

Vol. 17 No. 2

May - Ago 2020

Cúcuta, Colombia las personas cuando lleguen a un centro de salud ya están más preparados..."

\section{Triangulación Múltiple}

Los resultados de la triangulación se obtuvieron, a partir de las perspectivas teóricas abordadas y la información obtenida desde las categorías emergentes, producto del análisis de los datos cualitativos, frente a los fundamentos teóricos de la corriente Principialista y la Teoría Social de Alfred Schütz (22), tal y como se observa en la Imagen 1.

\section{Principialismo}

Se encontró interacción entre el principio bioético de beneficencia, expresado por los pacientes y el de justicia distributiva, manifestado por el personal de salud. Ambos emergen al momento de aplicación de la norma, que amplía el acceso a trasplante de órganos a más personas, que en la modalidad de donación altruista, era insuficiente para brindar mayor cobertura a pacientes en lista de espera. En este caso, la norma genera conflictos entre las éticas deontológicas de cada una de las profesiones participantes, frente a la posición que asumen los familiares de los donantes potenciales, ya que no todos aceptan la presunción legal de donación, al momento de aplicarse a sus allegados fallecidos.

Por ello es indispensable, la educación al personal, fortaleciendo el conocimiento sobre el marco legal de la do- nación, que se ve limitado por una inadecuada interpretación, originando dilemas entre el principio del respeto a la autonomía de la familia, y aspectos como el respeto a la privacidad y la confidencialidad; fundamentales para los allegados del donante. Dentro de este marco se hace necesario, que exista apoyo interdisciplinar, que pueda contribuir en una mejor comprensión de los dilemas que el proceso plantea; es decir, se sugiere transformar de manera consensuada los patrones que impiden un adecuado desarrollo de la nueva normatividad, al interior de cada una de las entidades de salud.

\section{Teoría Social de Alfred Schütz}

En el paciente la idea y/o el concepto de integridad personal, implica una mezcla de emociones y sentimientos, algo que para el personal de salud requiere de nuevos enfoques, integrados a los procesos de humanización y el apoyo de la bioética. El paciente expresa ciertos conocimientos sobre el tema, basado en sus vivencias, el nivel de comprensión y motivación; le hace un sujeto activo en la defensa de sus derechos reclamando la justicia en el acceso. De igual forma se percibe autónomo en sus decisiones. Las implicaciones e impactos sociales se apoyan en la expectativa ante la normativa, esto le permite interpretar su situación de una manera particular, a través de los conocimientos que tiene a su alcance, adquiridos durante la espera de un órgano, que mejore su calidad de vida.

Imagen 1. Triangulación Múltiple desde la Fuente de los Datos y la Perspectiva Teórica.

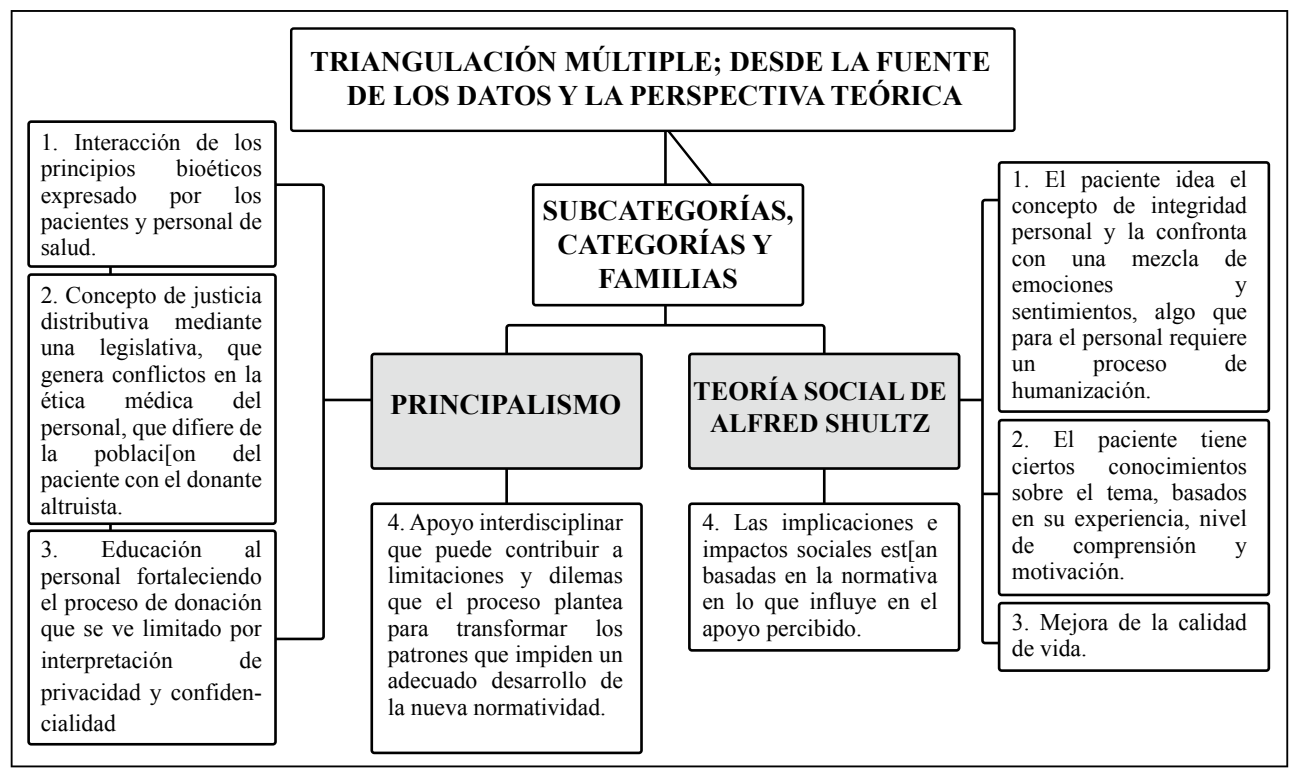

Fuente: Autores. 


\section{Discusión}

En un estudio sobre la ley de donación de órganos en Chile, la problemática se centra en la prioridad, que para los donantes establece la problemática evidenciada en los ciudadanos, dado que ven desde su perspectiva la donación como un proceso autónomo y de beneficencia, para muchas personas que están a la espera de un trasplante y que de cierta manera se vuelve equitativo para toda la población (23). Los hallazgos coinciden, con los principios de beneficencia, no maleficencia y de justicia distributiva, que se describen en la categoría "Bioética de la donación".

Sin embargo, un estudio advierte, que la relación entre presunción de donación y mayor disponibilidad de órganos no es inequívoca, pues la decisión de donar es muy sensible a la información disponible en el entorno. Se concluye que, si la información y los incentivos no son claros, los individuos pueden manifestar su negativa a la donación de órganos y, en consecuencia, el sentido de solidaridad en el interior de la comunidad podría ser sacrificado. Situación, que es similar a lo expuesto, por los participantes en la categoría dilemas (24).

De modo similar Cecchetto, establece que la relación entre identidad personal y trasplante de órganos es oscura, compleja y poco estudiada. [...] esa noción se involucra con una idea más general sobre el cuerpo humano, su naturaleza, funciones y alcances, y ella juega un papel importante en la decisión de donar y también en la de aceptar el órgano ofrecido por un tercero. Pero, al mismo tiempo, las sospechas enunciadas se mueven en el terreno de lo especulativo, por lo cual se tiende a desconocer los datos de primera mano que los propios individuos comprometidos aportan para esclarecer cuál es el vínculo que mantienen con su cuerpo, cuáles son sus percepciones, creencias y emociones, las imágenes y el valor que le otorgan a su corporeidad (25). Lo anterior se refleja en la categoría "Autopercepción y capacidad del actor para interpretar el mundo".

Por su parte Chaparro (24), considera que en todos los casos la bioética, con su conocimiento amplio de las posibilidades tecnológicas, su juicio en el estudio de las relaciones entre ética y derecho y su conocimiento del entorno, puede contribuir a identificar los peligros potenciales y proporcionar información útil, para que la población se haga partícipe de debates vitales, pues en temas como la donación y el trasplante de órganos, no solo se compromete la supervivencia y la calidad de vida de algunos individuos, sino que además definen los valores y el tipo de sociedad que queremos. Similar situación la expresan los pacientes en la categoría "Conocimientos Disponibles".

Un estudio, da cuenta de la experiencia de familiares que aceptaron la donación de órganos. Como resultados, se evidenció que las personas ven la donación como un proceso de beneficencia tanto para ellos, en caso de estar esperando un órgano, como para las vidas que ellos pueden salvar si donan sus órganos (26). En este caso la percepción de los pacientes en lista de espera, la consideran como una oportunidad, con "Implicaciones e impactos sociales".

La donación y el trasplante de órganos constituyen un prototipo de invasión sobre toda la vida del ser humano, a pesar de los supuestos beneficios para los trasplantados. La calidad de vida debe ser el criterio fundamental para evaluar los resultados de los trasplantes, inclusive más que los criterios estéticos prevalecientes en el concepto de salud, extendido culturalmente en la actualidad (27). La categoría "calidad de vida", da cuenta de esta ambigüedad, que origina una acción maleficente, por lo incierto de su desenlace.

Respecto a la categoría sobre Dilemas y justicia sanitaria se realizó un estudio en Brasil, sobre las "Vivencias de enfermeros en el proceso de donación de órganos y tejidos para trasplante" cuyo objetivo fue conocer la vivencia de los enfermeros en el proceso de donación. En el mismo se establecieron los obstáculos que se presentan durante el proceso, además refleja lo importante de tener en cuenta el cambio de paradigmas. Este estudio es relevante con respecto a nuestros resultados, debido a que los informantes expresan tanto las visiones de la sociedad como aquellas conductas que limitan el llevar a cabo el proceso de donación. Es decir, que, el personal de enfermería y el médico se enfrentan a situaciones éticas y de principios, dado que se abstienen de llevar a cabo lo correcto como lo establece la ley, para no enfrentarse a situaciones dilemáticas como lo son: sus ideas, valores personales, experiencias, creencias y consideraciones particulares (28).

En el trabajo "Roles de enfermería en los programas de trasplante de Colombia", se presenta una analogía respecto a los juicios morales que tiene el personal de salud, expresado como la satisfacción del deber cumplido durante el proceso de donación y trasplantes, sin importar lo mínimo o mucho que haga, pero el hecho de hacer 
parte del proceso le genera un sentimiento de superación. También, se expone el momento de enfrentarse a la familia como de tensión, sobre todo en la primera etapa en la que ingresa el paciente y en la que tiene que comunicar la noticia (29), situación que difiere en lo encontrado por el presente estudio. En este caso, el personal de cuidado directo, (cuando interviene la red de trasplantes), expresa que es apartado del cuidado del paciente y de sus familiares, aislándosele del proceso. En este sentido, el personal asistencial manifiesta que opta por marginarse de la actividad, aspecto que describe la categoría relacionada con "la educación al personal de salud y necesidad de fortalecer el estudio de la bioética".

Se puede señalar, que una de las fuentes filosóficas de la humanización en la atención en salud, se relaciona con la vertiente bioética, jurídica y filosófica, inspirada en la reivindicación de los derechos y los deberes, la autonomía y el respeto de la voluntad de los pacientes, como eje de la atención humanizada (30). En la categoría "humanización del proceso", es necesaria una mayor sensibilización, en torno al bien común de las personas, bajo una perspectiva que de forma prevalente, respete la vulnerabilidad y el sufrimiento humano.

Desde el principialismo, se destaca la interacción de principios bioéticos, así como el rol educativo del personal, que guarda relación con lo planteado por Ramos (31) [...], quien expresa que el personal profesional está expuesto a conflictos éticos derivados de su interacción con todos los actores del proceso de un trasplante, es decir, de su trato con las otras líneas del triángulo bioético y las de su propio equipo de trabajo. Por ello resulta importante que todos los profesionales involucrados, al margen de estar sujetos a las recomendaciones de un comité ex profeso de bioética, deben igualmente asumir su propio "código de ética del trasplante" dentro de este proceso de interacción con las otras líneas del triángulo.

De igual forma, en un estudio realizado con personal de salud teniendo en cuenta la Teoría Social de Schultz, se observa que ese actor social realiza intervenciones superando los obstáculos, con proyectos y expectativas a futuro; pero que al mismo tiempo tiene como meta cambiar los paradigmas de los profesionales de salud en relación a la donación de órganos y tejidos, permitiéndole humanizar el proceso, de tal forma que pueda ofrecer una asistencia digna a los familiares del potencial donador (28). Paradigmas que guardan relación con los impactos sociales percibidos y la calidad de vida del paciente.
Paralelamente, en una investigación sobre bioética y donación se plantean similitudes a lo expuesto por el personal de salud respecto a las normas, puesto que se convierten en respaldo al momento de abordar a las familias, para evitar problemas a futuro; además, hay concordancias al referir que la familia en muchos casos impone su criterio ante el fallecido (32). Lo expuesto anteriormente, se relaciona con la investigación actual, pues el personal expresa que algunos parientes se oponen a la extracción de órganos de su familiar, aun cuando en vida algunos estuviesen de acuerdo, y pese a que la norma lo establece, no lo autorizan. La dificultad se incrementa cuando las personas, en vida no manifies$\tan$ su deseo de donar. Esto hace que la familia asuma que la toma de decisión es de su competencia. En este caso gran parte del grupo participante considera, que esta es una forma de respeto hacia la autonomía de los familiares en duelo. El personal declara que hace falta trabajar la norma y darle una mayor aplicabilidad, en el campo de acción, pues se evidencia poca adherencia al marco normativo que rige el tema. En consecuencia, es necesaria una sensibilización normativa, pues la ley ha sido ineficazmente aplicada hasta el momento; otros consideran, que se deben realizar modificaciones, que permitan llenar los vacíos que la ley presenta.

\section{Conclusiones}

El personal de salud se enfrenta a dilemas bioéticos, que emergen con la implementación de la ley 1805 del 2016, que desencadenan en su labor, una serie de tensiones relacionadas, no solo con los principios bioéticos desde la perspectiva paciente -agente de salud, sino que además estos juicios y concepciones tanto morales como personales, los confrontan con la forma como desarrollan su práctica profesional. En contraste, las vivencias de los pacientes en lista de espera son de origen interno, ya que se sustentan de una parte en su experiencia (en busca de una oportunidad para mejorar su calidad de vida); y de otra, en las múltiples condiciones y requerimientos que exige el sistema para acceder a un órgano, en condiciones de igualdad, frente a los demás pacientes. Desde la perspectiva institucional, el personal de salud no observa cambios, en los criterios de las entidades, que favorezcan la implementación de esta nueva política. En el caso de los usuarios, la limitación en la aplicación normativa obedece a factores socioculturales, que les es imposible gestionar. En la región la norma no ha generado el impacto esperado en el fortalecimiento de la donación. 
La vivencia del personal de salud de la UCI sobre la presunción legal de donación está enfocada principalmente en el ámbito laboral; en este sentido, se encontró que existe una participación limitada y poco deseo de involucrarse activamente en el proceso. Esto genera frustración y poco apego al procedimiento que acompaña la implementación de la norma. Aun cuando el equipo multidisciplinario es una parte fundamental, los participantes expresan que ellos como equipo de salud, no intervienen en el proceso de acompañamiento a la donación; debido a que la red de trasplantes asume el proceso de manera directa, desde el momento en que se declara la muerte encefálica, hasta el rescate de órganos. Procedimiento que les excluye (de la interacción con la familia, restringe la participación del personal de salud en la preparación del cadáver para el rescate, incluida la extracción de órganos). Lo anterior hace, que este asunto sea visto como algo ajeno y externo a su labor, en donde "la red es la que se encarga", situación que fue común en los grupos focales de las tres entidades.

Las tensiones bioéticas que surgen en el personal de salud, que labora en los servicios de UCI se relacionan de manera directa con los casos de personas que en vida no consintieron donar. En este caso se pone de manifiesto el principio bioético de autonomía. En la interacción (Profesional-Familia-Cuerpo del paciente con muerte encefálica), el principio de justicia también genera tensión, al implementar el marco legal, frente a la negativa de las familias que desconocen los alcances e impactos de la norma.

En otras circunstancias los principios bioéticos, que rodean las tensiones experimentadas por el personal de salud se relacionan con la confrontación, entre la autonomía del paciente (cuando en vida ha expresado su voluntad de donar) y la autonomía que de forma subrogada busca ejercer la familia (cuando trata de oponerse a tal decisión por la vía legal). Este panorama pone en juego, la aplicabilidad del principio de beneficencia, que el paciente en vida expresó como su deseo de brindar una oportunidad de vida a otros, (que se encuentra en lista de espera). En este panorama la oposición de la familia puede originar, una probable situación de maleficencia (para los potenciales receptores de órganos), dejando en el vacío el principio de justicia, que la voluntad anticipada buscaba promover, a favor de un mayor grupo de personas vulnerables.

Los pacientes con enfermedad renal, que se encuentran en diálisis tienen diversas experiencias y vivencias alrededor de la ley de presunción legal de donación, pues para ellos entra en juego no solo la prolongación de su esperanza de vida (que puede ser mediada por la acción beneficiente que les proporcionaría un trasplante de órganos), sino que se relaciona con las realidades de su contexto. En este tipo de pacientes surgen una serie de tensiones dilemáticas internas, que están regidas por patrones culturales (que se representan en los imaginarios culturales y sociales), con los que perciben y adquieren su capacidad de interpretar (el mundo de la donación de órganos). Por consiguiente, la mediación de la educación debe proporcionar conocimientos que son necesarios para que el paciente, asuma conductas de autocuidado y protección. Del mismo modo, un mayor acceso a la justicia distributiva, en torno a las decisiones que se relacionan con los procesos de espera. Aun con las implicaciones e impactos sociales que viven, los pacientes siempre están en la búsqueda de mejorar su calidad de vida.

\section{Conflicto de Intereses}

Los autores declaran no tener ningún conflicto de intereses

\section{Referencias Bibliográficas}

1. Universidad de Antioquía [Internet]. UdeA Noticias; [citado 29 mar 2020]. Presunción legal de donación de órganos y sus implicaciones; [aprox. 2 p.]. Disponible en: https://bit.ly/2UP8vQV

2. Guerra Y, Vega P. El impacto social de la donación de órganos en Colombia. Revista Tend. Ret. [Internet]. 2012 [citado 20 de mayo de 2018]; 17(1):105-114. Disponible en: https://dialnet.unirioja.es/ servlet/articulo?codigo $=4929390$

3. Batista ACR, Silva OL Jr, Canova JCM. Atuação do enfermeiro no processo de doação de órgãos e tecidos para transplante. J Bras Transpl. [Internet]. 2012 [acceso 29 mar 2020]; 15(4):1689-1714. Disponible en: http://bit.ly/1ZUFWfH 
4. Rodríguez-Arias D. Bioética Universidad Complutense. [Boletín en línea]. 2012 [Consultado el 29 de marzo de 2020]. Disponible en: https://www.ucm.es/data/cont/docs/137-2016-02-18-Boletin\%20 12\%20Septiembre\%202012.pdf

5. Carrera JC. Los Fundamentos de la Bioética, de H Tristram Engelhardt. Bioética y Debat. [En línea]. 2011 [Consultado el 29 de marzo de 2020]; 17(64):12-16. Disponible en: http://www.bioeticayderecho. ub.edu/es/comentarios-al-libro-los-fundamentos-de-la-bioetica-de-hugo-tristram-engelhardt

6. Congreso de Colombia. Ley 1805 de 2016. [Internet]. 2016 [Citado el 5/05/2017]. Disponible en: http://es.presidencia.gov.co/normativa/normativa/LEY\%201805\%20DEL\%2004\%20DE\%20AGOSTO\%20DE\%202016.pdf

7. Instituto nacional de salud Colombia. Red Nacional de Donación y Trasplante de Órganos y Tejidos. [En línea]. [Consultado el 29 de mar 2020]. Disponible en: https://www.ins.gov.co/Direcciones/RedesSaludPublica/DonacionOrganosYTejidos

8. Ministerio de Salud y Protección social. Trasplante de Órganos en Colombia [Internet]. 2017 [Citado el 27 de julio de 2018]. Disponible en: https://www.minsalud.gov.co/Paginas/MinSalud-expide-circular-sobre-donacion-de-organos.aspx

9. Organización mundial de la salud. Informe sobre la situación mundial de las enfermedades no transmisibles 2010. Resumen de orientación [Internet]. 2011[citado 19 julio 2017]. Disponible en: https:// www.who.int/nmh/publications/ncd_report_summary es.pdf

10. Bonilla J. Bioética para enfermería: aspectos teóricos y prácticos [Internet]. [Citado el 18 de agosto de 2017]. EDIMEC p.145-166. Disponible en: http://www.dspace.uce.edu.ec/handle/25000/4823

11. Hermosin A, Pereira H, Nuñez A. Papel de la Enfermería en la donación de órganos. Revista Portales Médicos. [En línea]. 2017 [Consultado el 30 de marzo de 2020]; 12(20): 1-10. Disponible en: https:// www.revista-portalesmedicos.com/revista-medica/papel-de-la-enfermeria-donacion-de-organos/

12. Escobar-Triana J, Aristizábal-Tobler C. Los principios en la bioética: fuentes, propuestas y prácticas múltiples. Revista Colombiana de Bioética [Internet]. 2015 [Citado el 17/02/2018]; 6(3):76-109. Disponible en: http://dx.doi.org/10.18270/rcb.v6i3.1057

13. Álvarez-Avello JM, Santos JA. Análisis de los aspectos bioéticos en los programas de donación en asistolia controlada. Acta Bioethica [Internet]. 2014 [Citado el 17/02/2018]; 20(1):47-59. Disponible en: https://www.redalyc.org/articulo.oa?id=55431250002

14. Molina-Ramírez N. La bioética: sus principios y propósitos, para un mundo tecnocientífico, multicultural y diverso. Revista Colombiana de Bioética [Internet]. 2013 [Consultado 13 de abril de 2018]; 8(2):18-37. Disponible en: http://www.redalyc.org/articulo.oa?id=189230852003

15. Comité de bioética de Cataluña. Consideraciones éticas en los trasplantes de donante vivo. [Internet]. 2012 [Consultado 13 de abril de 2018]. Disponible en: https://canalsalut.gencat.cat/web/.content/_Sistema_de_salut/CBC/recursos/documents_tematica/consideracions_eticas_trasplantes_donante_vivo.pdf

16. Acevedo H. Perspectivas analíticas sobre la dinámica social: Aportes de la teoría social de Alfred Schütz para pensar la política y la acción colectiva. Trabajo y Sociedad. [En línea]. 2011 [Consultado el 13 de abril de 2018]; 15(17):83-94. Disponible en: https://www.unse.edu.ar/trabajoysociedad/17\%20ACEVEDO \%20Schutz\%20Alfred.pdf

17. Beauchamp, $\mathrm{T}$ y Childress J. Principios de ética biomédica. Capítulo 3: Respeto a la autonomía, pp. 113 - 173. Barcelona: Masson, 1999.

18. Mieles DH, Tonon G, Alvarado SV. Investigación cualitativa: análisis temático para el tratamiento de la información desde el enfoque de la fenomenología social. Rev universitas humanística. [En línea]. 2012 [Consultado el 31 de marzo de 2020]; 74(2):195-225. Disponible en: http://www.scielo.org.co/ pdf/unih/n74/n74a10.pdf

19. Betrián E, Galita N, García,N, Jove G, Macarulla M. La triangulación múltiple como estrategia metodológica. REICE Revista Iberoamericana sobre Calidad, Eficacia y Cambio en Educación. [En 
línea]. 2013 [Consultado el 30 de marzo de 2020]; 11(4):5-24. Disponible en: https://revistas.uam.es/ index.php/reice/article/view/2869/3086

20. Miles, M. B. y Huberman, A.M. Qualitative data analysis: An expanded sourcebook. (2a ed.). 1994. Thousand Oaks, CA: Sage.

21. Ministerio de salud y protección social. Resolución 8430 de 1993. Por la cual se establecen las normas científicas, técnicas y administrativas para la investigación en salud. [Internet]. 1993 [Citado el 12 de abril de 2018]. Disponible en: https://www.minsalud.gov.co/sites/rid/Lists/BibliotecaDigital/RIDE/ DE/DIJ/RESOLUCION-8430-DE-1993.PDF

22. Vallejo R, Mineira F. La triangulación como procedimiento de análisis para investigaciones educativas. Redhecs: Revista electrónica de Humanidades, Educación y Comunicación Social, [Internet]. 2009 [Citado el 16 de abril del 2018]; 4(7):117-133. Disponible en: https://ialnet.unirioja.es/servlet/ articulo? codigo $=3063110$

23. Rojas-Delgado P, Gutiérrez-Montaña M, Rojas-Rivera J, Saavedra-Ávila L, Ñancupil-Reyes W. Una mirada a la nueva ley de donación de órganos en Chile: la polémica prioridad para los donantes. Rev. Fac. Med. [Internet]. 2014 [Citado el 16 de julio de 2017]; 62(3):-477-480. Disponible en: http://www. scielo.org.co/pdf/rfmun/v62n3/v62n3a18.pdf

24. Chaparro GR. La presunción de la donación de órganos en Colombia: reflexiones para el debate. Rev. latinoam. bioet [Internet]. 2017 [citado 30 de marzo de 2020]; 17(33-2):92-106. Disponible en: https:// revistas.unimilitar.edu.co/index.php/rlbi/article/view/2178

25. Ceccheto S. Identidad personal y trasplante de órganos. Persona y Bioética [Internet]. 2009 [Consultado 30 marzo 2020]; 6(17):12-23. Disponible en: https://personaybioetica.unisabana.edu.co/index. $\mathrm{php} /$ personaybioetica/article/view/844/2025

26. Avilés L, Catoni MI, Rivera M. Donar, un cambio de vida: comprender la experiencia de familiares que aceptaron la donación de órganos. Rev. méd. Chile [Internet]. 2014 [citado 14 julio 2017]; 142(6):702-706. Disponible en: http://www.scielo.cl/scielo.php?script=sci arttext\&pid $=\mathrm{S} 0034-98872014000600003$

27. Quesada-Rodríguez F. Filosofía del cuerpo de Jean-Luc Nancy y Bioética de la trasplantología. Rev. latinoam. bioet. [Internet]. 2012 [Consultado 2020 Mar30]; 12(2):20-29. Disponible en: http://www. scielo.org.co/scielo.php?script $=$ sci arttext\&pid $=$ S1657-47022012000200003\&lng $=$ en

28. De Moraes E, Dos-Santos M, Aparecida-Barbosa MM, Komatsu-Braga MC. Vivencia de enfermeros en el proceso de donación de órganos y tejidos para trasplante. Rev. Latino-Am. Enfermagem [Internet]. 2014 [cited 2020 Enero 01]; 22(2): 226-233. Available from: http://www.scielo.br/scielo. php?script $=$ sci arttext\&pid $=$ S0104-11692014000200226\&lng $=$ en

29. Forero É. Roles de enfermería en los programas de trasplante de Colombia. Universidad Nacional de Colombia. Bogotá. [Internet]. 2012 [Citado 14 abril 2018]. Disponible en: http://www.bdigital.unal. edu.co/6508/1/Ericamildredforeroariza.2012.pdf

30. Santacruz-Bravo JD. Humanización de la calidad en la atención clínica en salud desde la perspectiva centrada en el paciente a partir de la Resolución 13437 de 1991. Rev Univ. Salud. [Internet]. 2016 [Citado 30 marzo 2020]; 18(2):373-384. [Disponible en: http://www.scielo.org.co/pdf/reus/v18n2/v18n2a17.pdf

31. Martínez K. Algunos aspectos éticos de la donación y el trasplante. Anales Sis San Navarra [Internet]. 2006 [citado 2020 Mar 30]; 29(Suppl 2):15-24. Disponible en: http://scielo.isciii.es/scielo. php?script=sci_arttext\&pid=S1137-66272006000400003\&lng=es

32. Victorino J, Aparecida VC. Donación de órganos: tema bioético a la luz de la legislación. Rev. Bioét. [Internet]. 2017 [cited 2019 July 01]; 25(1): 138-147. Available from: http://www.scielo.br/scielo. php?script $=$ sci_arttext\&pid $=$ S1983-80422017000100138\&lng $=$ en 